\title{
Data-Driven Approaches for Circular Economy in Manufacturing for Digital Technologies: A Review of Current Research and Proposed Framework
}

\author{
Okechukwu Okorie ${ }^{1 *}$, Konstantinos Salonitis ${ }^{1}$, Fiona Charnley ${ }^{2}$, Mariale Moreno ${ }^{2}$, Christopher \\ Turner ${ }^{3}$ and Ashutosh Tiwari ${ }^{4}$ \\ 1 Cranfield University, School of Aerospace, Transport and Manufacturing, MK43 0AL, Bedfordshire, \\ United Kingdom; o.s.okorie@cranfield.ac.uk; k.salonitis@cranfield.ac.uk; \\ 2 Cranfield University, Centre for Competitive Design, School of Water, Energy and Environment, MK43 \\ 0AL, Bedfordshire, United Kingdom; f.charnley@cranfield.ac.uk \\ 3 University of Surrey, Rik Medik Building, Surrey Business School, Guildford, Surrey, GU2 7XH, United \\ Kingdom; Christopher.turner@surrey.ac.uk \\ 4 The University of Sheffield, Amy Johnson Building, Department of Automatic Control \& Systems \\ Engineering, Portobello Street, Sheffield, S1 3JD, United Kingdom; a.tiwari@sheffield.ac.uk \\ * Correspondence: o.s.okorie@cranfield.ac.uk; Tel.: +44-7859153124
}

\begin{abstract}
The Circular Economy has been of growing significance within academic, policymaking and industry groups. Latest developments in the field of Circular Economy has led to an expansion of CE studies focused on interrogating CE as a paradigm, its relationship with sustainability and concepts and definitions of the Circular Economy. Research has also identified the significant potential of applying circular approaches to areas of the economy, including manufacturing and Industry 4.0, which, with data, is enabling latest the advances in digital technologies. This is the first review paper to integrate the fields of $\mathrm{CE}$ and digital technologies resulting in a framework which provides directions for policymakers and guidance for future research. To achieve this, we conduct a systematic literature review of the empirical literature related to digital technologies, industry 4.0 and circular approaches, from the point of the 9 Rs. The systematic literature review (SLR) is based on peer-reviewed articles published between 2000-2018. The findings reveal that while research on the circular economy has been on an annual rise, research on digital technologies enabled circular economy is still relatively an untouched area of research across all nine (9) circular approaches. As such this is an area rife for further research. This paper also presents illustrative charts and graphs to summarize the current trends in circular economy research in manufacturing. From this, a framework for future circular economy research for manufacturing for digital technologies is proposed.
\end{abstract}

Keywords: Circular Economy, Industry 4.0, Data, 9R's, Digital Technologies, Digital Intelligence

\section{Introduction}

Certain factors have driven the need for the transition towards more sustainable, intelligent sociotechnical systems. These include economic challenges and economic instabilities for individual companies and entire economies, [1], rising global population which has put pressure on already scarce resources [2], other environmental challenges such as biodiversity loss and depletion of important natural resource, [3], [4] and other social issues such as high unemployment in certain parts of the world, poor working conditions [5], widening inequalities [5], etc. There have been systematic investigations since the 1960's that have focused on understanding the impact of these challenges on society its sustainability. Findings have generally indicated tension [6] and also raised valid questions in the sustenance of prosperity trends in the society [7]. Clearly, the prevailing economic model, of "take, make, use and dispose" -or the linear economy -was incompatible in society sustenance and 
economic growth. Thus, since the circular economy model has origins in the linear economy, it is important to critically examine this as a prime enabler of the circular economy.

Dating back to the Industrial Revolution of 1760-1820, the linear economy model is framed largely around "consumption", where the product is "consumed" in design and use and then disposed, a unidirectional model of production, [8]. Thus it could be described as linear or, as in Figure 1 [9] below as an incomplete circle which starts at the point of extraction and "ends" at the point of disposal. The product resource is extracted as much as possible during its useful life; product efficiency and the economic terms of GDP growth is not prioritised in a linear economy model. Research shows that this model is unsustainable; current consumption stands at $50 \%$ rate faster than it can be replaced [10]. At the current growth rate the global middle class would have doubled by 2030 [10] and, [with the increase in population] driving demand for resource-intensive goods described as a requirement which is more than two plants worth of natural resources, [8].
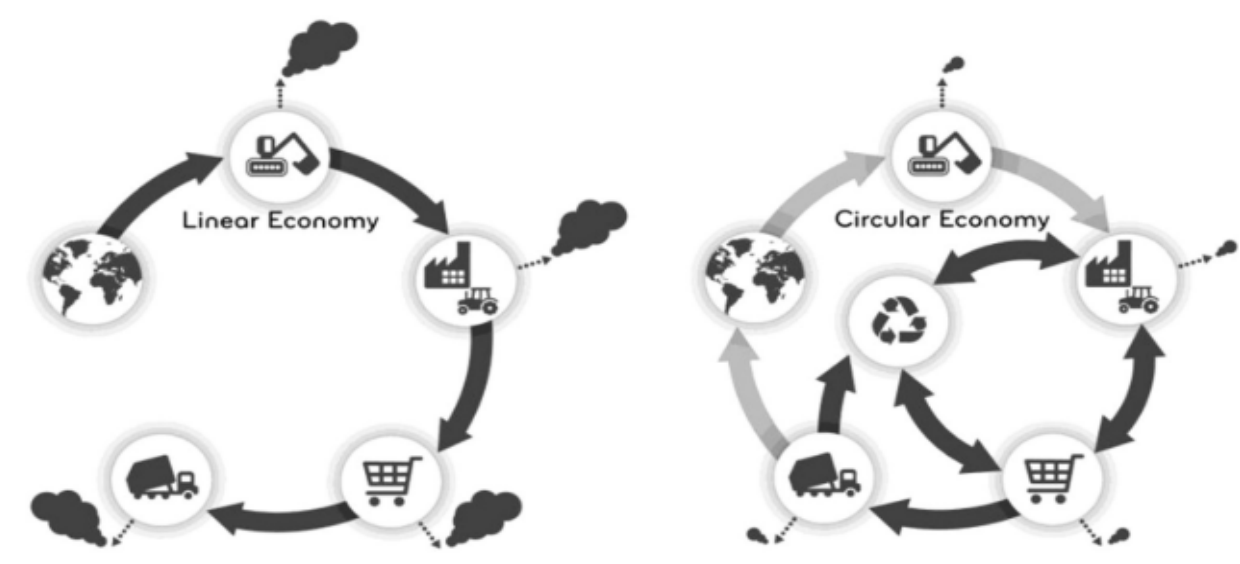

Figure 1. (L-R) Linear economy concept indicating an incomplete loop where the plant provides the extracted resources and receives the waste after the resources have been used. The Circular Economy concept is a more optimal system where the product is kept in use as long as possible and recycled at the end of its life.. Adapted from [9]

The unsustainability of the linear economy drove the development and implementation of the Circular Economy (CE) as an alternative resource model where economic growth is decoupled from virgin resource consumption. For a definition, the "Circular Economy" is not without its complexities; Kirchherr et al, (2017) [11] gathered 114 definitions of the circular economy which were analysed for their dimensions and thinking. Differences in CE definitions are partly due to the fact that the concept is employed by different stakeholders. Thus, as argued in [12] and [13] blurring of the concept of CE can occur since it is used in very different schools of thought. Review articles identified in [14], [15], [16], [2] and [17] also mentions this criticism of the CE as well as concept such as the green economy. In their comprehensive review of CE concepts, [11] this complexity was further highlighted from various analysed literature. For example [18] argued that "there are various possibilities for defining [CE]"; [9] suggests that this complexity in definition of CE is augmented by the fact that CE is a "trans-disciplinary research" while [19] stress that there is no commonly accepted definition of [CE]. As the $\mathrm{CE}$ is of interest to academia, industry and policymakers [20] definitions on the CE has been proffered or adopted by these categories. Overall, CE, is not a new concept; [21] reminds us that the term has existed since the 1970s while [22] states that it appears in academic literature in 1990 by Pearce \& Turner[23] where the linkages between the environment and economic activities were analysed. Approaches deployed to enable circularity, hence the circular economy, which we shall describe as "Circular Economy Approaches" or "Circular Approaches" are no new 
Table 1. Most recent reviews of the circular economy (CE) paradigm.

\begin{tabular}{|c|c|c|c|c|}
\hline \#\# & Authors & Focus & Journal & Circ. Approach in Keywords/Sections \\
\hline 1 & Ghiselli et al. (2016) [16] & Review of 155 articles on the CE & Journal of Cleaner Production & Recycling, Reuse, Remanufacturing \\
\hline 2 & Murray et al. (2017) [17] & $\begin{array}{l}\text { Comparison of CE concept and } \\
\text { sustainable business }\end{array}$ & Journal of Business Ethics & Recycling \\
\hline 3 & $\begin{array}{l}\text { Lieder and Rashid (2016) } \\
\text { [14] }\end{array}$ & $\begin{array}{l}\text { A review of } C E \text { in the context of } \\
\text { manufacturing industry. }\end{array}$ & Journal of Cleaner Production & Reduction, Reuse, Remanufacturing \\
\hline 4 & Lewandowski (2016)[24] & $\begin{array}{l}\text { A review (conceptualisation) of } \\
\text { business models for CE }\end{array}$ & Sustainability MDPI & - \\
\hline 5 & $\begin{array}{l}\text { Geissdoerfer et al. (2017) } \\
\text { [2] }\end{array}$ & A review of $C E$ and sustainability & Journal of Cleaner Production & - \\
\hline 6 & Sauvé et al. (2016) [9] & $\begin{array}{l}\text { Comparison of CE concept and } \\
\text { sustainable business }\end{array}$ & Environmental Development & - \\
\hline 7 & $\begin{array}{l}\text { Blomsma and Brennan } \\
\text { (2017) [15] }\end{array}$ & $\begin{array}{l}\text { Explanation of the emergence of the } \\
\text { CE concept }\end{array}$ & Journal of Industrial Ecology & - \\
\hline 8 & Su et al (2012)[25] & Review of CE implementation & Journal of Cleaner Production & \\
\hline 9 & $\begin{array}{l}\text { Kirchher } \\
\text { et al. (2017) [11] }\end{array}$ & $\begin{array}{l}\text { Comparison and analysis of } 114 \mathrm{CE} \\
\text { definitions }\end{array}$ & $\begin{array}{l}\text { Resources, Conservation \& } \\
\text { Recycling }\end{array}$ & Reduce, Reuse, Recycle, Recover \\
\hline 10 & $\begin{array}{l}\text { Cattelan Nobre et } \\
\text { al., (2017) [21] }\end{array}$ & Big data and IOT & Scientometrics & - \\
\hline 11 & Mast et al, (2017) [26] & Supply Chain & Sustainability & - \\
\hline
\end{tabular}


concepts. The 3R principles of "Reduce", "Reuse" and "Recycle" are highlighted in [27] and have been studied and highlighted in academic literature since the early 1950's and many other existing literature while concepts such as "Remanufacture"[28], "Reverse Logistics" and "Refurbishment", gained increasing traction in academic literature from 1984 onwards[28]. It must be explained, at this point, what the Circular Economy is; the most common circular approaches will be analysed in this paper. According to [29], the Circular Economy (CE) is "an economic system that represents a change of paradigm in the way that human society is interrelated with nature and aims to prevent the depletion of resources, close energy and material loops, and facilitate sustainable development". As well as being concise, this definition leverages on the broader definition (and much cited definition) of Ellen Macarthur Foundation [30] and shall be adopted as the overarching definition of this paper.

\section{Objective of Paper}

Table 1 shows previous reviews of the circular economy (CE) concept after expanding reviews in [11] and search was performed on SCOPUS and Science Direct. As seen in Table 1 various reviews of the CE literature have centered on analysis of the various CE definitions, sustainability and CE in the supply chain. Academics in other fields, such as the fields of business, management and strategy have added to the growing literature on CE by focusing on circular business models, CE implementation strategies and value-thinking (Brocken et al, 2016 [31], Lewandoski, 2016 [24], Reike, et al 2018 [32]). Manufacturing-related CE research has included Leider and Rashid, [14] which explored the different ideas, motivation for research and context of manufacturing within CE. It is understood that [33] digitization and the various concepts of the Industry 4.0 (I4.0) can boost the transformation towards a more sustainable circular economy. There is no paper, however, that reviews the integration of 14.0 and digital technologies with the Circular Approaches of, reuse, remanufacture, recycling, recover energy, refurbish, repurpose, refuse, reduce, rethink and repair. We refer to these circular approaches as data-driven approaches -circular approaches enabled by data or other components of I4.0

The objective of this paper is to therefore to critically assess and synthesize the empirical literature related to data-driven approaches for circular economy in manufacturing for digital technologies as well as developing a framework by which circularity research for digital technologies can be understood and assessed.

The concepts of Industry 4.0 can enable the Circular Economy by building visibility and intelligence into products and assets such as real-time condition of the assets, location and availability of assets, [33]. As 14.0 concepts advance, their uses within the CE further increases. The utilization of artificial intelligence or blockchain technology, for example, [34] is bringing novel ways to improve traceability and transparency throughout a product time. As I4.0 becomes a pervasive feature today, it will be important to understand the interactions with the CE. The existing literature that discusses the integration of CE approaches and 14.0 is very limited, despite the acknowledged importance of this integrated study, [35]. Studies, where they exists, have focused on the 3R's of reuse, recycle and remanufacturing [36] and lack comprehensiveness. There is, thus, a significant research gap in understanding the state of art of research in this area, for policymakers and academics. Answering the question this research gap poses is a key motivation for this research. We aim to provide important lessons for policy-makers and academics by proposing key avenues for further research

This paper focuses on data-driven circular approaches for digital technologies in manufacturing, tracking their development and trend in academic literature. By this aim, we shall challenge what is, as observed from Table 1, seemingly the "boundaries" of CE review research, which focuses on business models, sustainability, CE concepts and a broad view of manufacturing. There are also industrial reasons for this research. Already components from I4.0 dominate today's world; according to [37] there were over 10 billion connected devices in 2006 and this will increase to 25-50 billion connected devices by 2020 generating trillions of data points. The connected devices have been seen to have a contributing effect in virtually all sectors of the economy, [37] and also the natural environment [24]. For instance, according to [38] of the 141 million mobile device thrown away in the 
US, $89 \%$ of them were disposed in landfills. Understanding how digital technologies and concepts of I4.0 enables circularity has not been investigated in research [27] and, at best, is still unclear [36]. Furthermore, papers on industry 4.0 and the circular economy on one hand and circular approaches and the circular economy are largely discussed in research separately.

In this SLR key avenues for further research shall be proposed. The remainder of this paper is structured as follows: Section 2 describes the method and analytical design employed in this SLR. The process of papers selection is described in Section 3. Section 4 presents the descriptive analysis of the literature found under various useful categorisation. In Section 5, the main results are described after the content analysis of papers carried out in the previous section, allowing us to propose a framework for further research on the topic. This framework is defined and described in Section 6. Section 7 contains the conclusions of this paper, limitations and research implications.

\section{Review Methodology}

This research shall be based on a Systematic Literature Review, or the SLR. Thus, the sections and the review methodology shall be designed according to the SLR method as highlighted in [39] by Tranfied et al, (2003) a paper which has received over 1,100 citations since published in 2003. In conducting this research, requirements such as thoroughness and depth were deemed as important to this research. Traditional methods of research has been criticized for lacking these requirements, [39]. The SLR has been proposed as a detailed type of research which takes into consideration the broad foundation, [21] as well as being transparent, explanatory, heuristic[40], context-sensitive and able to achieve evidence-informed reviews and decisions, [39]. Thus, the need for a systematic literature review in the review of data-driven circular approaches in manufacturing for digital technologies is predicated on the view that SLR can help this research identify research trends, identify future work in the area and the tools used in solving the problems being addressed, [41]. Figure 2 below describes the systematic literature review phases

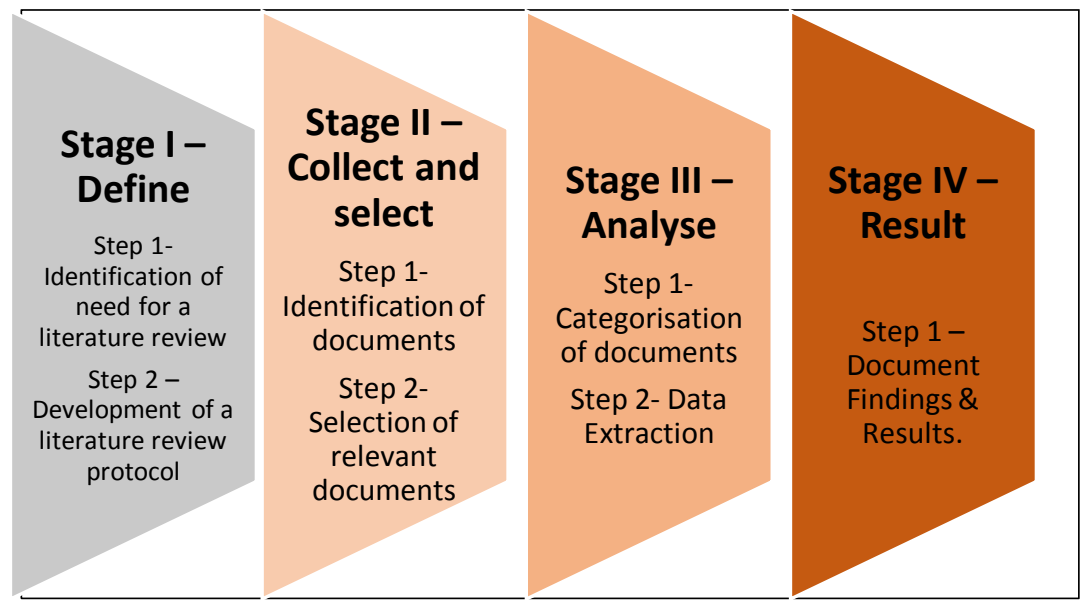

Figure 2: Systematic literature review phases. As adapted from Tranfield et al. [39]

The systematic literature review process is in four different stages, as shown in Figure 2 above. Stage 1 is defined as, "Define"; here the need for a literature review is identified (as identified in the Introduction) and also, a literature review protocol is developed. Stage 2 is the "Collect and select"; here documents for research are identified and from the pool of identified documents, relevant documents are selected. Stage 3 is the "Analyse" stage; here documents selected in Stage 2 are categorized and data is extracted from it. Stage 4 is the "Result" stage. Here the trends and data are analyzed and reported as findings, [39].

For this research, Scopus scholarly database is utilized. Various reasons exist for this choice of database. SCOPUS has been described as a viable alternative to Eugene Garfield's Science Citation 
Index [42] and has been consistently found to have a greater overall coverage of academic journals, [43] \& [44]. Scopus also presents best practice in terms of comprehensiveness, [42]. This "comprehensiveness" of SCOPUS over Web of Science can be seen in this example: When the search string, ("Industry 4.0" OR "digital technolog*" OR "manufactur* data" OR "digital intelligen*”) AND ("circular econom*") were entered in both databases, Web of Science returned 4 results and SCOPUS returned 14 results for the period selected "All Years". Google Scholar was not utilized as valid questions still persists in terms of its suitability for research evaluation due to the low data quality found in Google Scholar, [43]. As this research specifically focuses on understanding trends and not comparison of research trends from scholarly databases, it will be justified to focus on one identified comprehensive database, SCOPUS, despite cited drawbacks of SCOPUS such as its unsuitability for humanities and social science-type research, [43].

We build the literature review protocol as identified in Table 2. First we establish the period 2000 to 2018 as the period which the literature review will be developed on. The systematic literature review study starts with the identification of keywords, applied as search strings. These keywords and search arguments are developed from the scoping study of the research, the literature consulted and finally agreed by the research team. As corroborated in [41], it is an iterative process that requires protocol refinement for approval. This is shown in Figure 3. The main keywords used for this search were "Industry 4.0", "digital technologies" and "manufacturing data". Boolean operators "AND" and "OR" are utilized. Defining the search string, however, was slightly less straightforward. "Circular Economy" was first defined as a search string, as this is the key theme of this research. Circular approaches, however, was slightly more problematic due to the many "Rs" in literature. Lacy and Rutqvist in their book "Waste to Wealth" referred to the 3 Rs of "Reduce", Reuse" and "Recycle" [27] which has also been cited in a number of literature, [45], [46], [47], [26], [29] \& [32]. Other R framework includes the $4 \mathrm{R}$ framework of "Reduce", "Reuse", "Recycle" and "Recover"[11] and the 6Rs as first proposed by Joshi in 2006; these are "Reduce", "Reuse", "Recycle", "Recover", Redesign" and "Remanufacture", [48]. Other scholars [49] \& [49] have extended the frameworks into the 9Rs which are "Refuse", "Rethink", “Reduce", "Reuse", “Repair", "Refurbish", “Remanufacture", "Repurpose", "Recycle" and Recover". In the choice of these frameworks as search strings for this paper, it is important to briefly understand the underlying reasons posed for the development of the $3 R^{\prime} s, 4 R^{\prime} s$, $6 R^{\prime} s$ and 9R's. The 3R framework is proposed as the most prominent R framework [11] and is at the core of many Circular Economy implementation drive in countries, including the 2008 CE Promotion Law of the People's Republic of China. The 3R's have been argued to relate to mainly waste management policies, [16]; hence the $4 R^{\prime} s, 6 R^{\prime} s$ and $9 R^{\prime} s$ were proposed as a more comprehensive and integrated framework for circularity, with the 9R's possibly the most nuanced one, [11]

In selecting the circular approach to utilize as search string, it would be important to note two facts; firstly, the conference paper [36] presented at the $18^{\text {th }}$ European Roundtable on Sustainable Consumption and Production already utilizes "reuse", "recycling", "remanufacturing" and "sustainability" as search strings hence, for this research, a more comprehensive list of approaches is needed. Also, it is important to understand that all new varieties of the $\mathrm{R}$ framework move in order of increasing circularity -from the linear economy to the circular economy, where "refuse", "rethink" and "reduce", strategies were observed to be more useful in smarter product use and manufacture. However, the gradations of circularity makes it clear that "refuse" (preventing the use of raw materials) is the first option for circularity and "recover energy" or "recover" is the final option for extracting value from resources[50]. Thus, while recycling and energy-recovery are at the heart of circularity gradations, a comprehensive review of the circular economy, must include the options in the middle. Thus, the 9R's will be utilized as search strings. 
Table 2: Literature Review Protocol

\begin{tabular}{ll}
\hline Item & Description \\
\hline Time Period & January 2000 to June 2018 (Search was performed in June, 2018) \\
Boolean Operators & AND between keywords; OR between Database search fields. \\
Search fields & "Industry 4.0"; "Digital Technologies"; "Digital Intelligence"; \\
Language & "Circular Economy"; “9R's" \\
Availability & Articles available online as full text \\
Research Discipline & Engineering; Business; the Sciences excluding Medical Science. \\
Exclusion Criteria & Articles unrelated to search words; \\
Publication type & Peer-reviewed academic journals; conference papers. \\
\hline
\end{tabular}

We restrict the language of the search to English as this is the language with the largest number of publications and universality, hence more likely to offer useful papers. The search string was defined in this manner: (("Industry 4.0" OR "Digital Technolog*" OR “Digital Intelligence") AND ("Circular Econom*)); this is described in Table 3. This search string did not guarantee that only papers within the research topic will be returned, hence an exclusion criteria was defined. Thus the returned papers were subjectively examined by reading through their titles and abstract ensuring the exclusion of papers that did not address the research area.

Table 3: Modification of the search string

\begin{tabular}{|c|c|}
\hline Database & Search string \\
\hline SCOPUS & $\begin{array}{l}\text { ((“Industry 4.0" OR “Digital Technolog*” OR “Digital Intelligence" OR } \\
\text { "Digital Manufactur*” AND (“Circular Economy")) Refine by: } \\
\text { Language: (ENGLISH) AND Subject Area: Exclude by subjective } \\
\text { analysis of paper title and abstract which falls outside research context } \\
\text { AND Source Type: (CONFERENCE PAPER) AND (JOURNAL } \\
\text { PAPER) AND (CONFERENCE REVIEW)) }\end{array}$ \\
\hline SCOPUS & 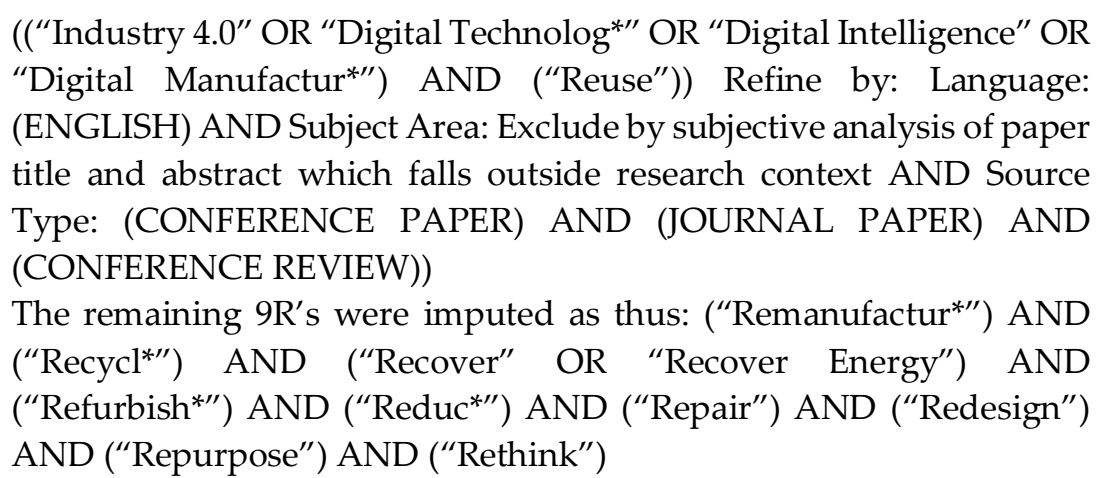 \\
\hline
\end{tabular}

Document type was spread across journal papers and conference reviews and conference papers. While studies show that journal papers especially higher ranted journals are considered to provide a high quality of research [51], research into circular economy and industry 4.0 and its concepts have been described as "emerging research" in [35] and [45]. Thus, it was important to consider for this research, new discussions around industry 4.0 and circular approaches from all sources including conference papers. The next section describes the process employed in the selection of relevant papers. 


\section{Paper Selection Methodology:}

Inclusion and exclusion criteria chiefly describes the paper selection process in any methodological review. According[52] and [53] defining an inclusion and exclusion criteria is important in generating an unbiased review of literature which also focuses on the context of the research [54]. In their research focusing on energy efficiency and environmental sustainability in supply chain management context [52] and [53] go on to propose three selection criteria which shall be adopted in this work to produce the paper selection criteria.

Table 4: Papers Selection Criteria

\begin{tabular}{ll}
\hline Selection Criteria & Tasks Performed \\
\hline $\begin{array}{l}\text { 1st selection criterion: } \\
\text { Focus of abstract }\end{array}$ & $\begin{array}{l}\text { Here we focus on title and abstract in materials which relates to the } \\
\text { research context identified for this research. Papers outside this } \\
\text { criterion were removed. }\end{array}$ \\
$\begin{array}{l}2^{\text {nd }} \text { selection criterion: } \\
\text { focus of paper }\end{array}$ & $\begin{array}{l}\text { Papers focusing on Circular Economy and each of the 9R's were } \\
\text { identified and considered. Papers with missing abstract, broken links, } \\
\text { were excluded. }\end{array}$ \\
$\begin{array}{l}\text { 3rd selection criterion: } \\
\text { citation method }\end{array}$ & $\begin{array}{l}\text { Papers not included in the selected academic database (SCOPUS) but } \\
\text { circular approaches were considered }\end{array}$ \\
\hline
\end{tabular}

It is important to define keywords utilized as search strings, to ensure that keywords are utilized in their proper context. Figure 3 as adopted from [49] defines the terms in 9Rs. 


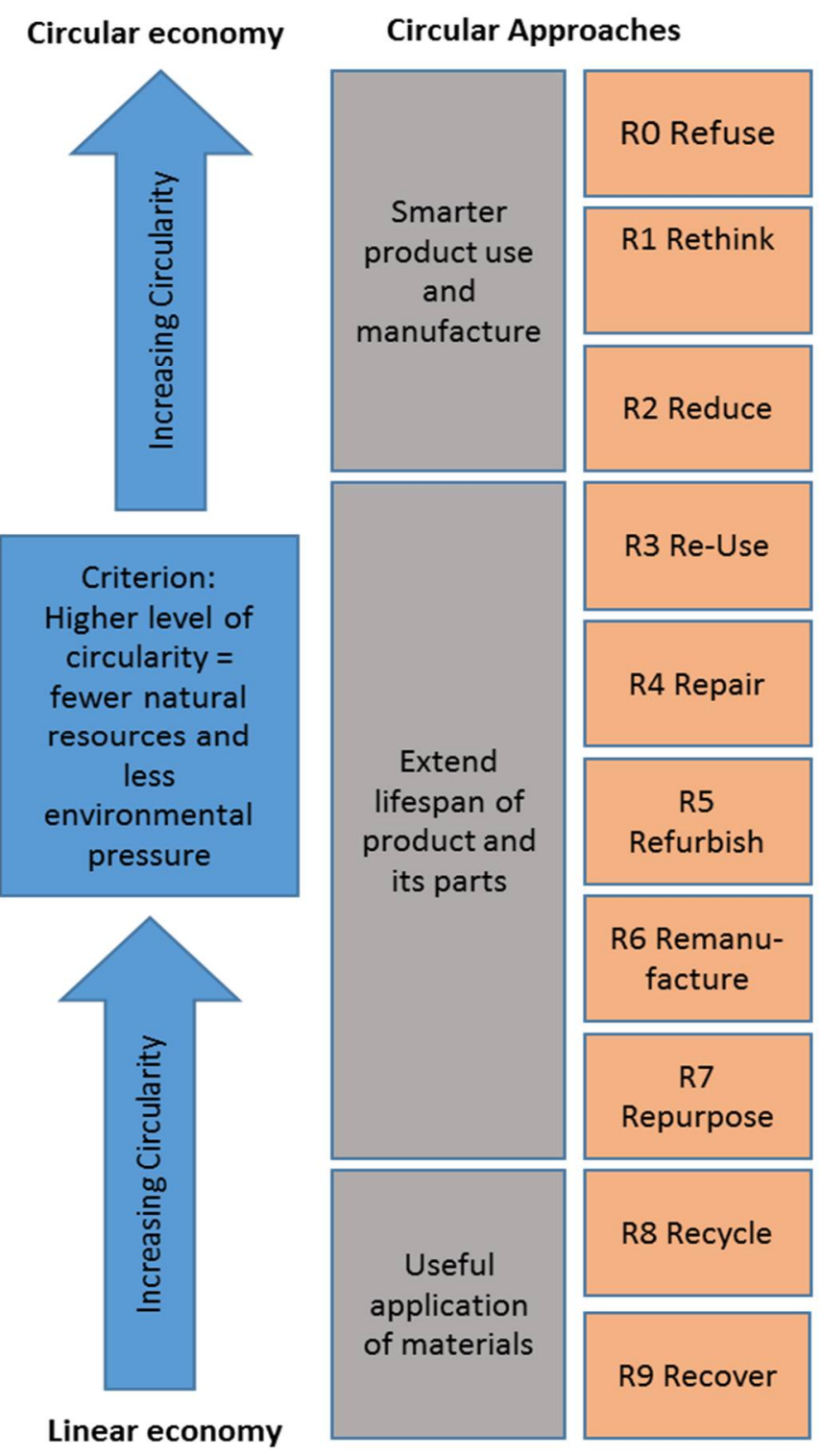

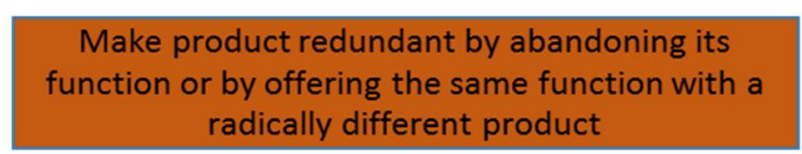
Make product use more intensive (e.g. through sharing products, or by putting multi-functional products on the market)
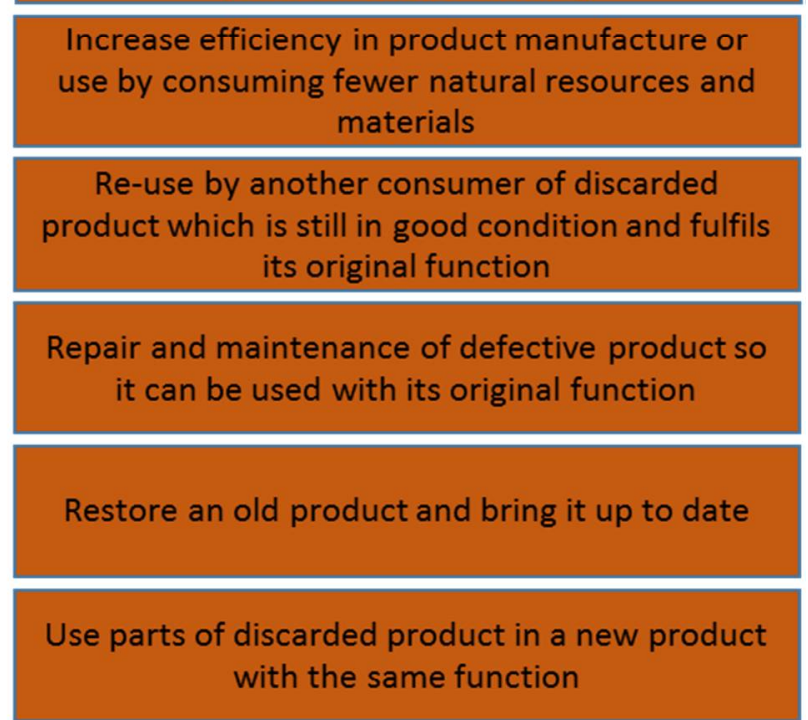

Use discarded product or its parts in a new product with a different function

Process materials to obtain the same (high grade) or lower ((low grade) quality

Incineration of materials with energy recovery

Figure 3: The 9R Framework of Circular Approaches with the production chain in order of priority.

Source: Adapted from Potting et al, (2017, p.5)[49]

Using the paper selection method described in Table 4, the initial results produced after "Circular Econom" "was utilized as search string, that is (“"Industry 4.0" OR "Digital Technolog*” OR "Digital Intelligence" OR "Digital Manufactur*" AND ("Circular Economy")) was 15 papers. This was further revised to 12 after the exclusion criteria was applied. Table 5i gives the paper selection before and after the selection criteria was applied. 
Table 5i: Paper selection with search strings

\begin{tabular}{lll}
\hline Search String Keyword & Initial Result & After Exclusion Criteria \\
\hline "Circular Econom"” & 15 & 12 \\
"Remanufactur"” & 9 & 7 \\
"Reuse" & 59 & 35 \\
"Recycl" & 44 & 18 \\
"Recover" OR “Recover & 137 & 49 \\
Energy" & 65 & 27 \\
"Repair" & & \\
"Reduc" AND “Circular & 3 & 2 \\
Economy" & 4 & 0 \\
"Refuse" & 0 & 0 \\
"Repurpose" & 66 & 11 \\
"Rethink" & 18 & 13 \\
"Refurbish" & & \\
\hline
\end{tabular}

When the search string (("Industry 4.0" OR "Digital Technolog*” OR “Digital Intelligence" OR "Digital Manufactur*" AND ("Reduce")) was applied 488 results were yielded. This is due to the possibility that the word "reduce" was likely to appear in articles where it was not used as a circular approach. Thus, the search string (("Industry 4.0" OR “Digital Technolog"” OR "Digital Intelligence" OR "Digital Manufactur" AND ("Reduce") AND ("Circular Economy")) was applied and this yielded an initial result of 3 articles further reduced to 2 after the exclusion terms had been applied.

Table 5ii: Paper selection with search strings and Circular Economy

\begin{tabular}{lll}
\hline $\begin{array}{l}\text { Search String Keyword with } \\
\text { "Circular Economy" }\end{array}$ & Initial Result & After Exclusion Criteria \\
\hline "Remanufactur"” & 0 & 0 \\
"Reuse" & 2 & 1 \\
"Recycl" & 2 & 1 \\
"Recover" OR "Recover & 0 & 0 \\
Energy" & 0 & 0 \\
"Repair" & 3 & 2 \\
"Reduc" & 0 & 0 \\
"Refuse" & 0 & 0 \\
"Repurpose" & 0 & 0 \\
"Rethink" & 0 & 0 \\
"Refurbish"” & & \\
\hline
\end{tabular}

Thus, a total of 174 papers were selected from 420 papers after the title, abstract of the articles and the exclusion criteria in Table 4 . This is a discard percentage of over $100 \%$; according to [55] a high discard rate after initial literature review is not uncommon. The main reasons for exclusion were that the discarded papers were of the wrong language, did not deal with the subject of digital technologies, industry 4.0 and either of the circular approaches. The text was analyzed carefully and the final 174 articles were eligible for SLR as shown in Table 5i. However, a second search string was deployed with ("Circular Economy") AND the circular Approaches in the 9Rs in order to ascertain articles which examined the 9R's within the specific context of circular economy research. The initial result was 7 papers and a total of 4 papers after the exclusion criteria was applied. More importantly, this was not spread across all of the approaches as some of them returned zero results. The implication of this is discussed in the next section. Figure 4 illustrates the review and paper selection process in a flow diagram. 


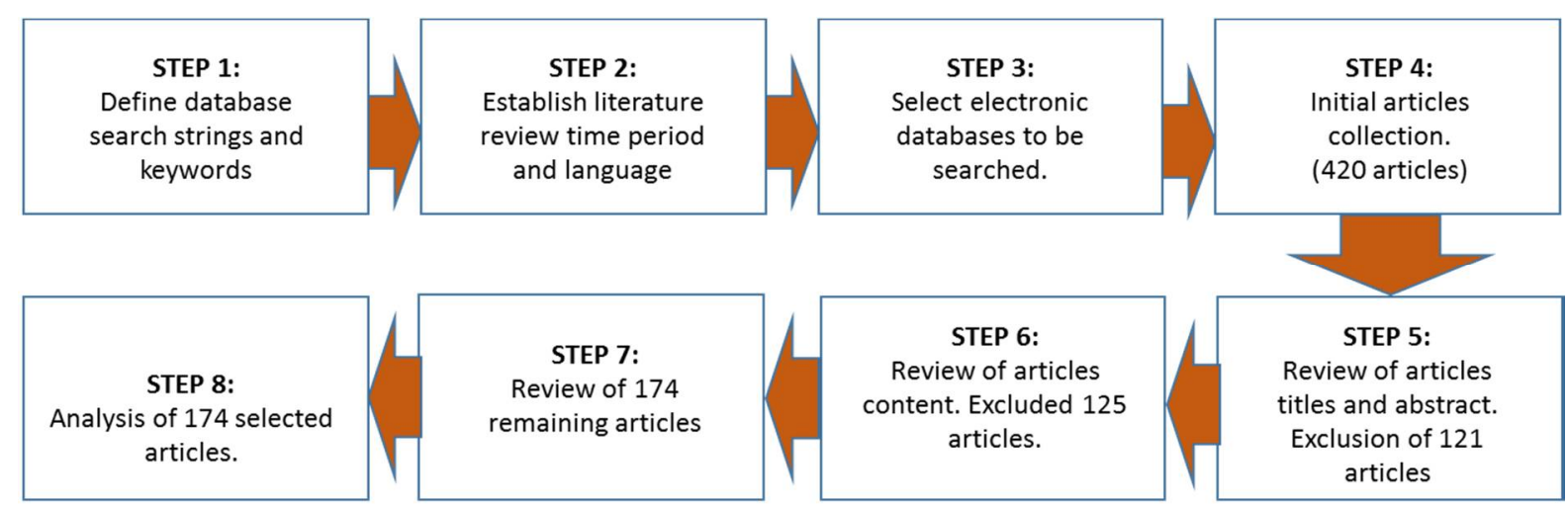

Figure 4: Flow Diagram indicating the Review Process

\section{Descriptive Analysis of the Literature.}

Descriptive analysis of the papers is employed to give a mainstream view analysis of the selected articles for the research area involving I4.0 and circular approaches. The aim is to examine 9R's as captured in Potting et al, [49] the results and trends from the 174 papers are combined in Figure 5. Thus, in order to describe the trend in a year, we combine the 9R's in a single graph instead of analyzing each approach in 9 different graphs. We evaluate the 174 selected papers according to the following identified perspectives: (1) Circular economy papers across years. (2) Circular approaches papers across years. (3) Papers across journals and conference papers. (4) Papers by geographical distribution. (5) Papers by subject area.

\subsection{Circular economy papers across years}

The time distribution for the research was set at 2000-2018, an 18 year span. 2000 was set as the beginning of the time distribution as there has been observed to be an evolution in circular economy studies and models since the early 2000s, [45].

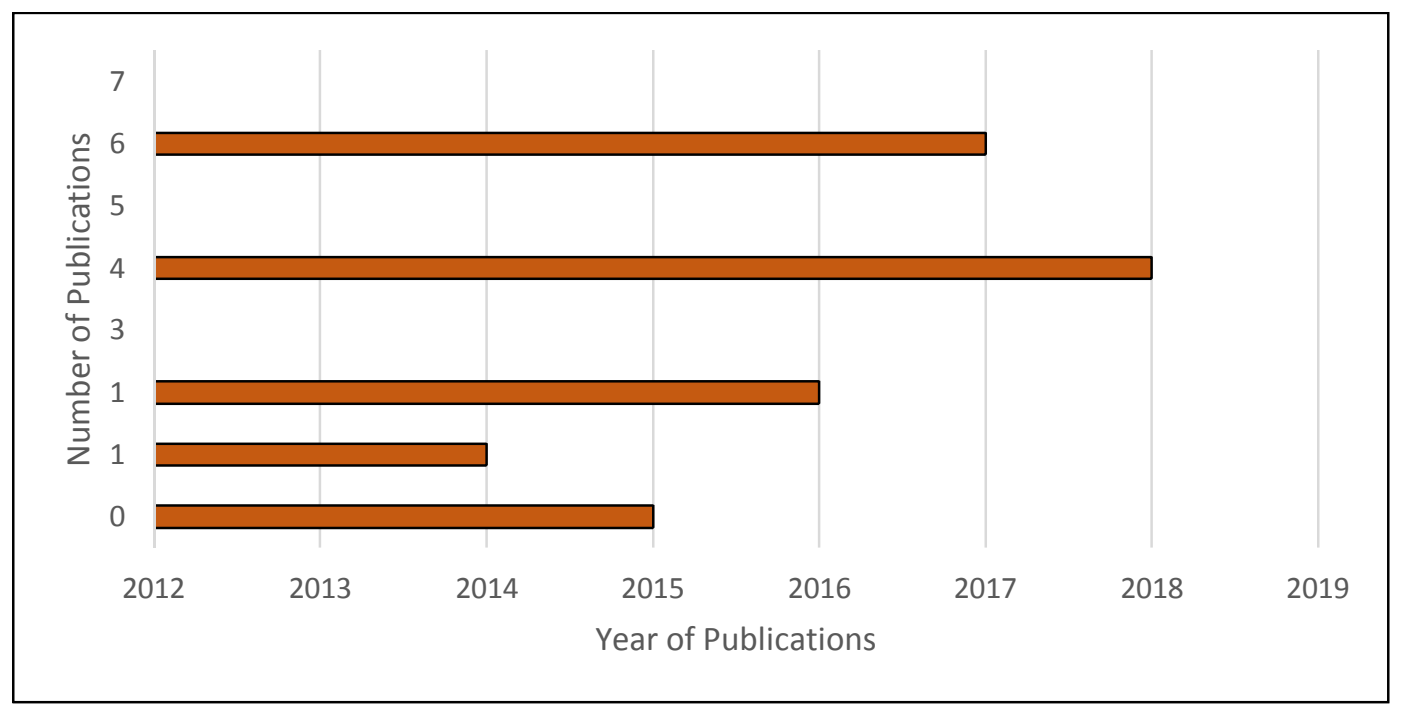

Figure 5: Number of Publications vs Year of Publications for circular economy and Industry 4.0

According to the distribution over a period of time, there were no identified relevant papers on Scopus from 2000 to 2014 which focused on Industry 4.0 and the circular economy. Specifically, 
papers on this subject only started in 2014 (1 paper) and peaked in 2017 with 6 identified papers. In the paper by Jabbour et al [35], examining a viable research agenda for Industry 4.0 and the Circular Economy, identified technologies for Industry 4.0 were highlighted in papers published in 2015, 2016 and 2017, confirming the recentness of the research. Thus, the trend of the research indicates a research area which is new and is steadily growing.

\subsection{Circular approaches papers across years}

The selected papers distribution across the years, 2000 - 2018 has been analyzed for the following circular approaches; Refuse, Rethink, Reduce, Reuse, Repair, Refurbish, Remanufacture, Repurpose, Recycle and Recover. Despite being described as 9R's, as first coined in [49], it must be observed that this list contain 10 different approached. The reason for this, as put forward in [49], is that R0 (Refuse) and R1 (Rethink) only decrease the consumption of natural resources and materials applied in a product chain by less of the product being needed (or reused) for the same function. We combine the circular approaches in a single graph as illustrated in Figure 6 below.

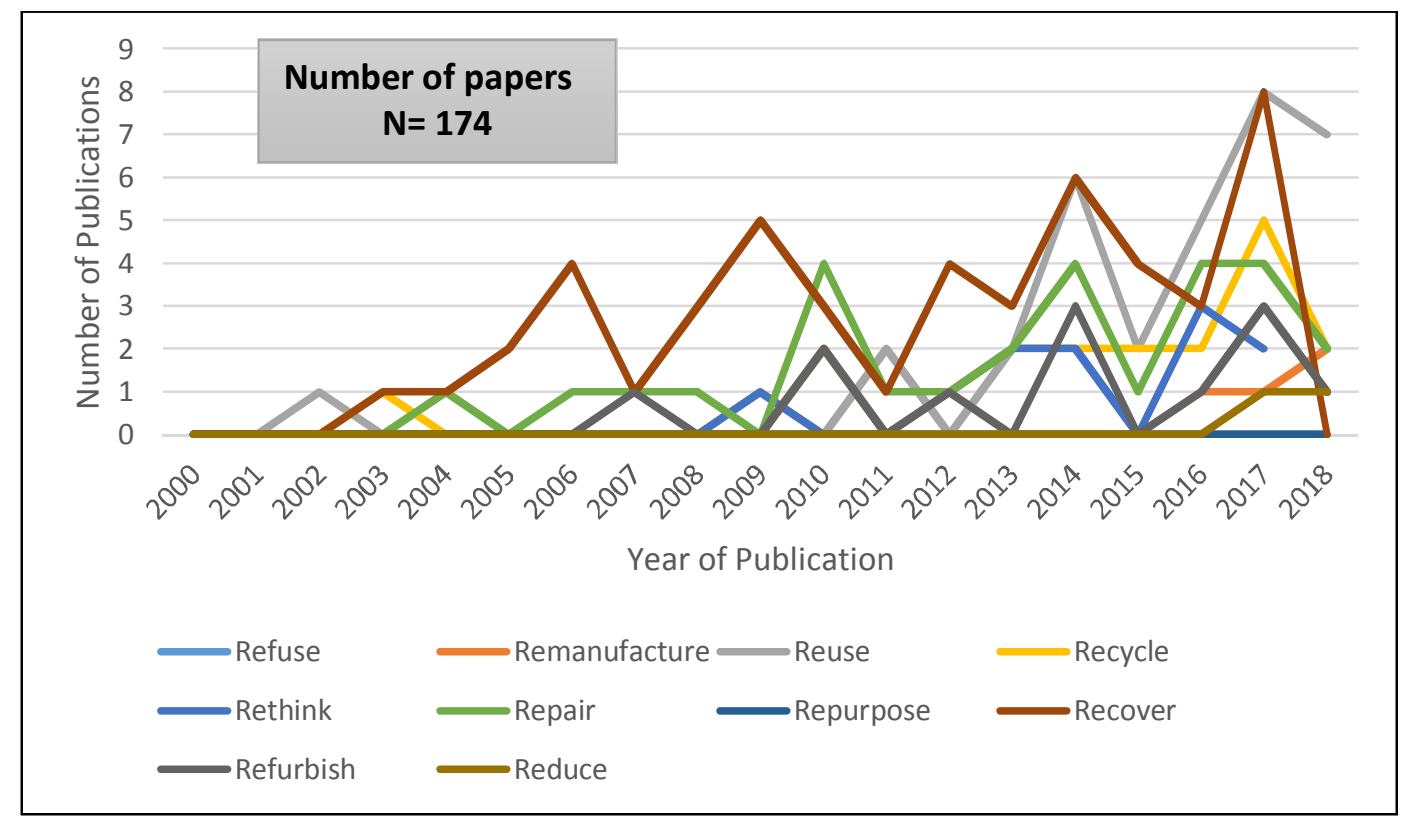

Figure 6: Number of Publications vs Year of Publications for circular approaches and Industry 4.0

Research into data-driven/ industry 4.0 enabled circular approaches shows a general increase, with peak in 2014 and 2017. There were no research in this area in the years for 2000 and 2001, thus reiterating that CE is an emerging concept, as highlighted in several literatures, [45], [11] and [14]. The focus in literature, however, is observed to be on recycling, recover, reuse as circular approaches where I4.0 is employed, while approaches such as remanufacturing appears to be on a slower growth rate in comparison to the aforementioned in research. There are several possible reasons for this; papers on energy where devices employed in the energy sector are increasingly been fitted with sensors and other data collection devices, [35]; recycling is still viewed as important by policymakers (resource efficiency specialists at WRAP estimate that only 117 million tonnes out of 540 million tonnes of products entering the UK annually get recycled [56]) and hence the continued research in the academia, [57], while remanufacturing is still being traditionally driven [28] as disassembly, cleaning, refurbishment of component parts and reassembly are labor-intensive processes where the experience of the workers are more important over the use of sensors in machines, for example [28]. We note that refuse and repurpose do not make up any part of the selected articles. Possible reason for this is the fact that "refuse" refers to the product no longer needed in the product chain and 
"repurpose" is still viewed as a major strategy in the linear economy [49]. However, the major conclusion from the analyzed publications is that the trend of papers is one of continued growth in recent years.

\subsection{Papers across Journals and Conference Papers}

The type of paper reviewed were determined by the identified subject areas. The functionalities provided by the SCImago Journal Rank (SJR) platform, helped identify 9 subject areas relevant to the research area. These include; "Engineering", "Energy", "Computer Sciences", "Decision Sciences", "Mathematics", "Business, Management and Accounting", "Chemical Engineering", "Material Science" and "Environmental Science". This wide range of subject area reflects the multidisciplinary nature of the research area. Articles selected included journal papers, conference papers, book chapters and review papers which is denoted by "others". Figure 7 illustrates the type and quantity of articles across the various circular economy approaches

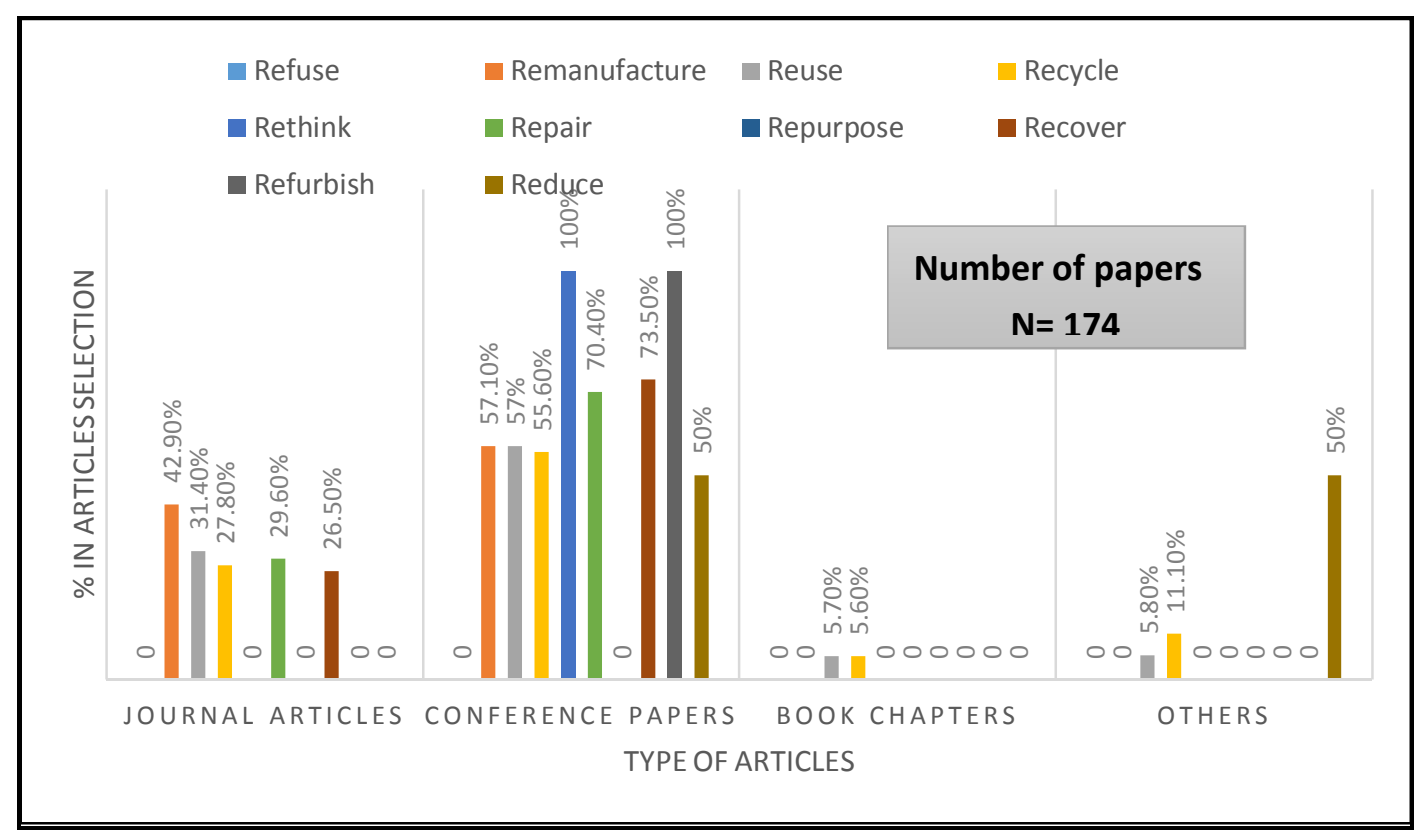

Figure 7: Papers distribution across Journals and Conference papers by numbers

Figure 7 highlights (and reiterates) two important aspects of this research. Firstly, conference papers makes up about $70 \%$ of all literature found in this research area, across the $9 R^{\prime}$, , while journal papers make up $19 \%$ of selected literature. Several possible reasons for this emerge. These include the relative novelty of this research area [35] leading to researchers focusing on conferences where the matrix of CE, Industry 4.0 and CE approaches are the focus. According to Roets \& Botma, [58] while conference papers form the basis of a subsequent journal publication, many challenges prevent this happening. Access to data and industry collaboration are highlighted as key [59] reasons as these are required for article submissions into high quality journals. The second aspect of this research is the prevalence of remanufacturing within journal articles (42.90\%) and conference papers $(57.10 \%)$. Thus, a conclusion that can be reached on this is that research focusing on enabling CE and remanufacturing with $\mathrm{I} 4.0$ is of equal importance to academics and industry. 


\subsection{Papers by Geographical Distribution}

Research publications were drawn out of 34 countries with the USA providing the most publications. Figures $8 \mathrm{a}$ and Figure $8 \mathrm{~b}$ shows the paper distribution across countries of publications.

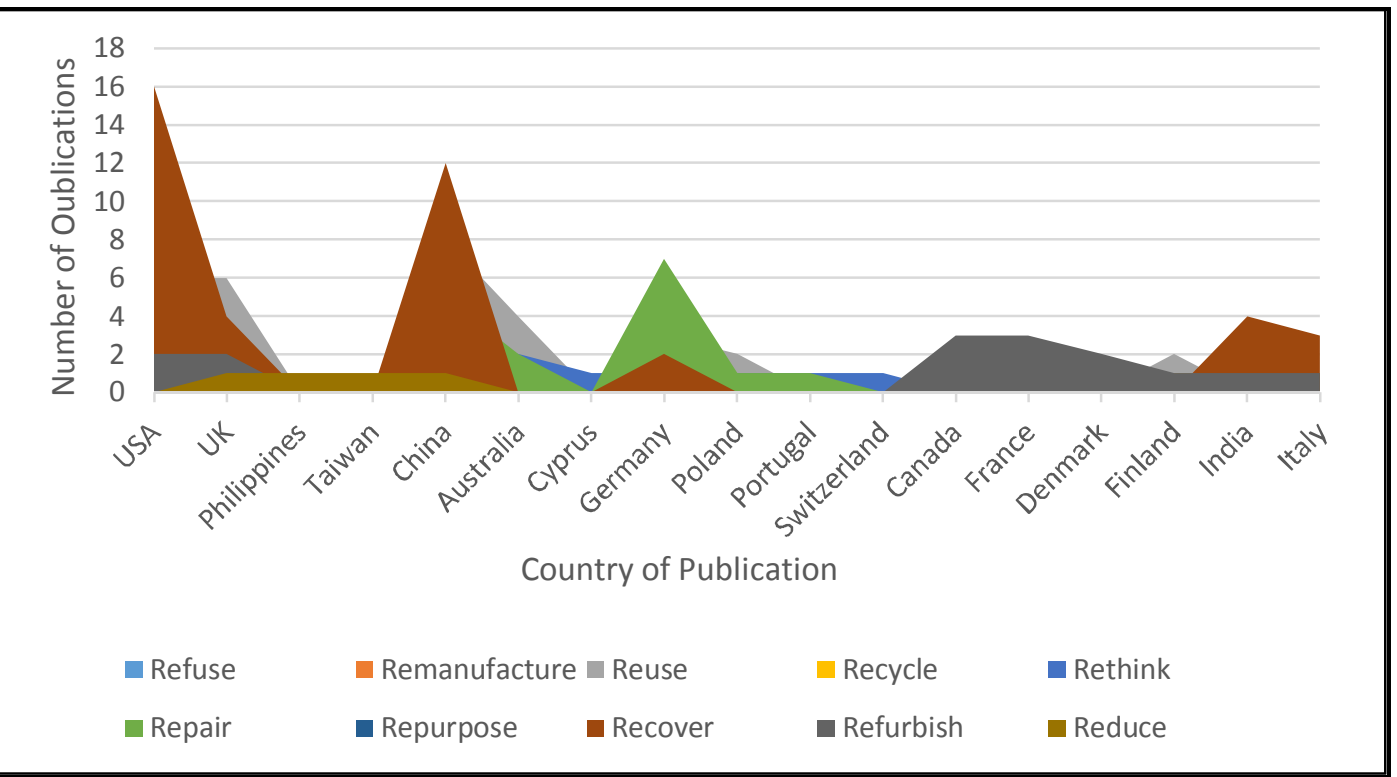

Figure 8a: Papers distribution across countries of publication (a)

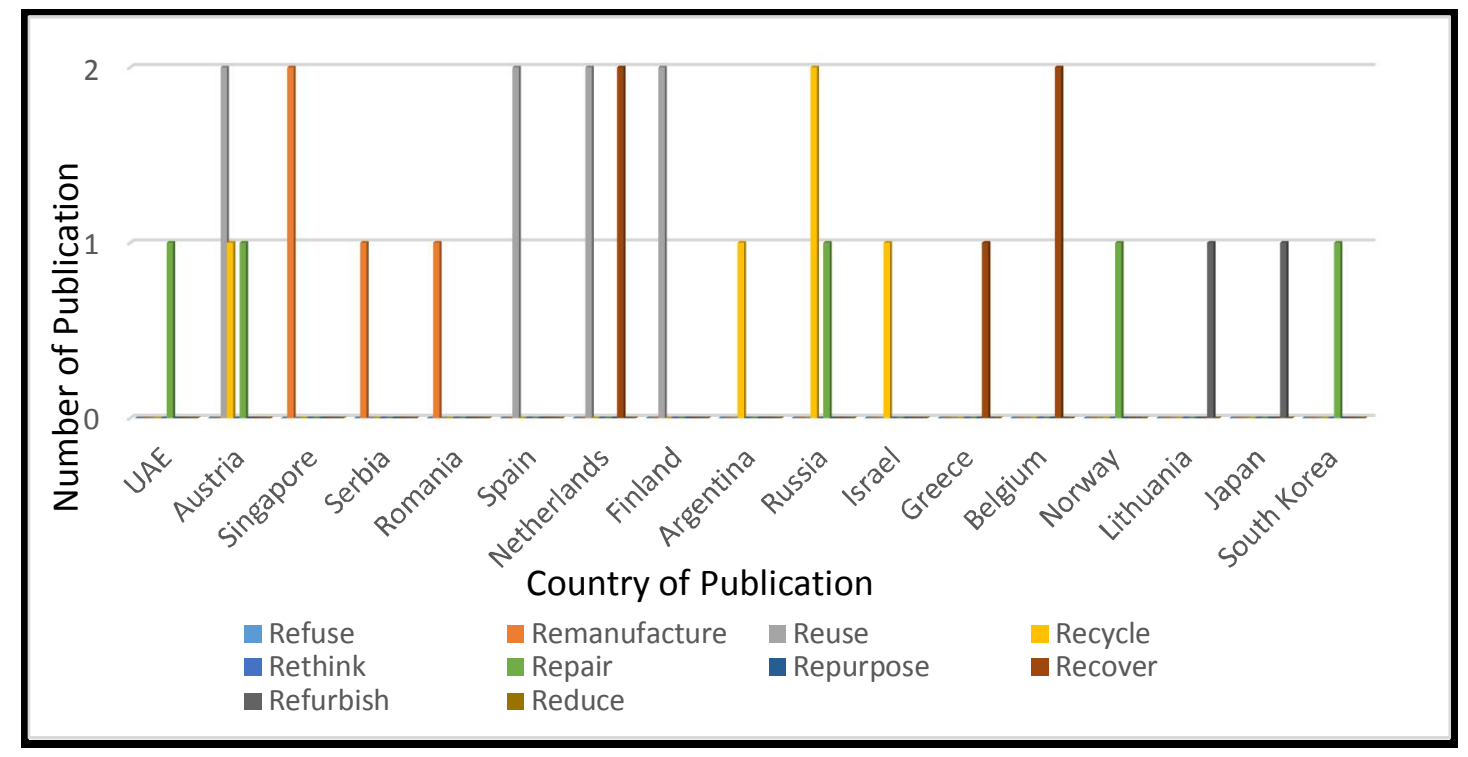

Figure 8b: Papers distribution across countries of publication (b)

Asides the US, China, the UK and Germany predominate in terms of total research. The reasons for these are varied; since launched in 2008, the Circular Economy is a sustainable development strategy proposed by the central government in China [25] with the aim to improve efficiency of materials and energy use, [60]; research into utilizing sensors to recover energy and has been consistent in the United States since the 1980's[28], however, this interest appear to diminish in remanufacturing in the United States, [61] as evident in the graph. Circular Economy research and enabling the CE through digital manufacturing and digital intelligence is a key strategy in the UK largely driven by 
the Engineering and Physical Sciences Research Council, EPSRC, [62]. However, the low number of publications in this research area largely indicates that the objectives of these policies, especially using I4.0 to enable the $\mathrm{CE}$, has not fully being achieved. A sectoral analysis of the chart by regions indicate the most of the research is coming from Europe (20 out of 34 of the countries). As the European Commission has specifically adopted a CE package to drive Europe's transition towards a circular economy, this level of interest is not unexpected[63].

\subsection{Papers across subject area}

Eight (8) functional subject areas in this research area were identified based on the number of papers published. These include "Engineering", "Energy", "Computer Sciences", "Decision Sciences", "Material Science", "Business, Management and Accounting", "Chemical Engineering" and "Environmental Science". Other subject areas, (designated as "others" in Figure 9) include agricultural science, economics, physics and mathematics. Thus this area of research can be rightly classified as "multidisciplinary" owing to a plethora of academic areas. Figure 9 below illustrates these academic areas as a proportion to the number of papers found.

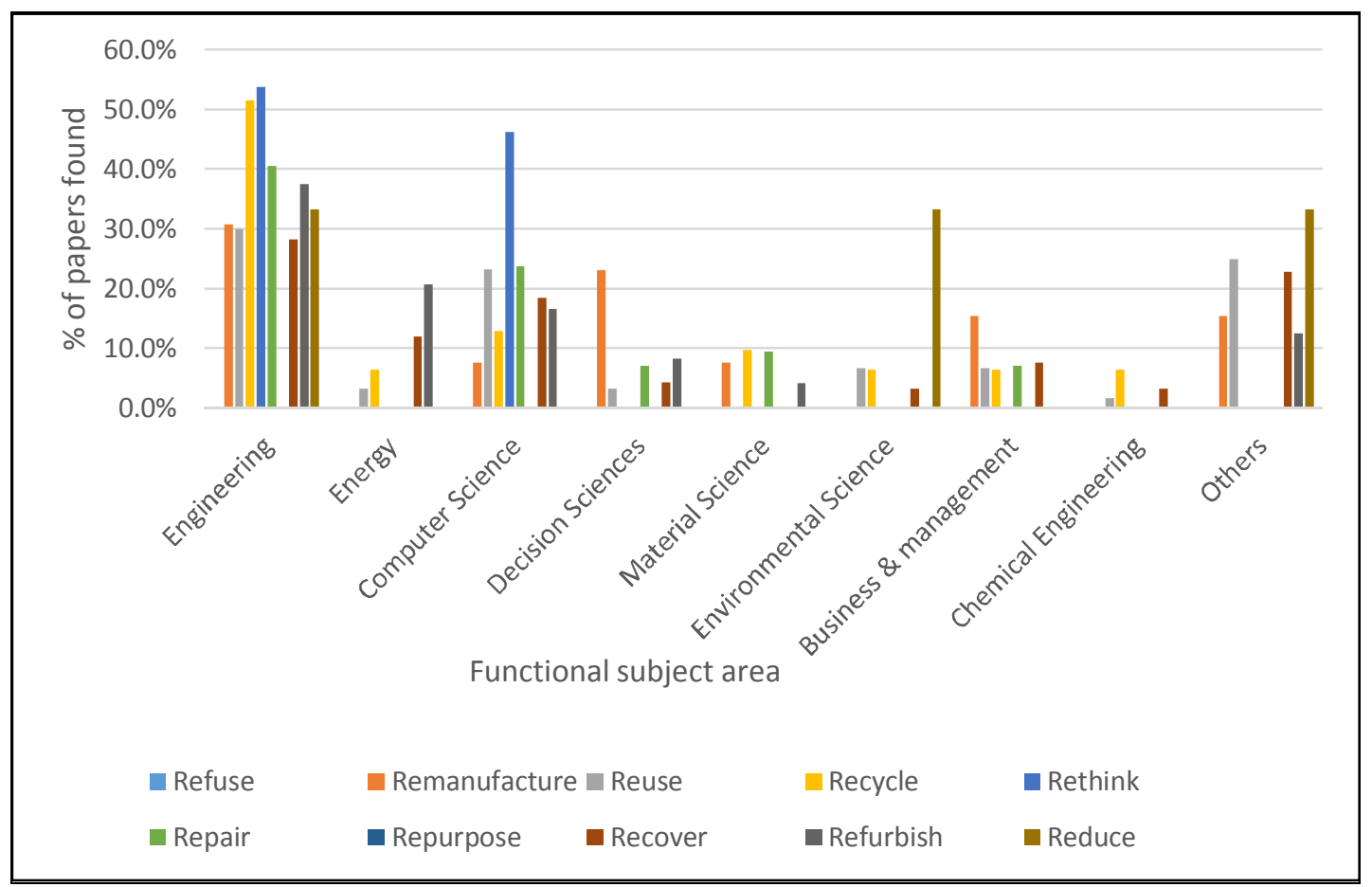

Figure 9: Papers distribution across subject area and circular approach

Predominant subject areas in this research include engineering, computer sciences, which are also populated with the most circular approaches in this research. Research in "rethink", "recycle" and "repair", respectively make up $54 \%, 52 \%$ and $41 \%$ of papers under engineering subject area. Research in "rethink" and "repair" make up $46 \%$ and $24 \%$ of papers in computer sciences. There were no subject areas for the circular approaches, "repurpose" and "refuse".

\section{Content Analysis and Framework}

In this section, we aim to provide a content analysis of the 174 selected papers in a manner which provides detailed clarity on observations from the previous sections. Detailed content analysis of the selected paper is also aimed at proposing a framework for future circular economy research in 
manufacturing for digital technologies can be proposed. The following sections shall examine the observations of the research.

\subsection{Analyzing the aspect of multidisciplinary research in I4.0 for CE research}

Interdisciplinary research or multidisciplinary research has been observed to be a key feature from the systematic literature analysis in the previous section. Also referred to as "transdisciplinary or interdisciplinary research", [64] one definition for transdisciplinary research is a research which is aimed at achieving a holistic and comprehensive picture of the problem at stake, requiring an open and complex research design [65]. Driven by collaborations[64], multidisciplinary research is important for research solutions which are both complex and demand innovative solutions, [66]. However, Huutonemi et al [67] argues that a single definition for multidisciplinarity is tricky since the inherent complexity in multidisciplinary research stems from the many parts and many stakeholders involved in this research. Thus, while no consensus exists on how to measure multidisciplinary research in practice [68] certain indicators are proposed for this in [67]. These includes the "scope of interdisciplinarity" (these includes the subject area, topic area) and the "type of interdisciplinary reaction" between fields and projects. (Topic areas are subsets of subject areas). Figure $\mathbf{1 0}$ below indicates observations of multidisciplinarity in the research area under review.

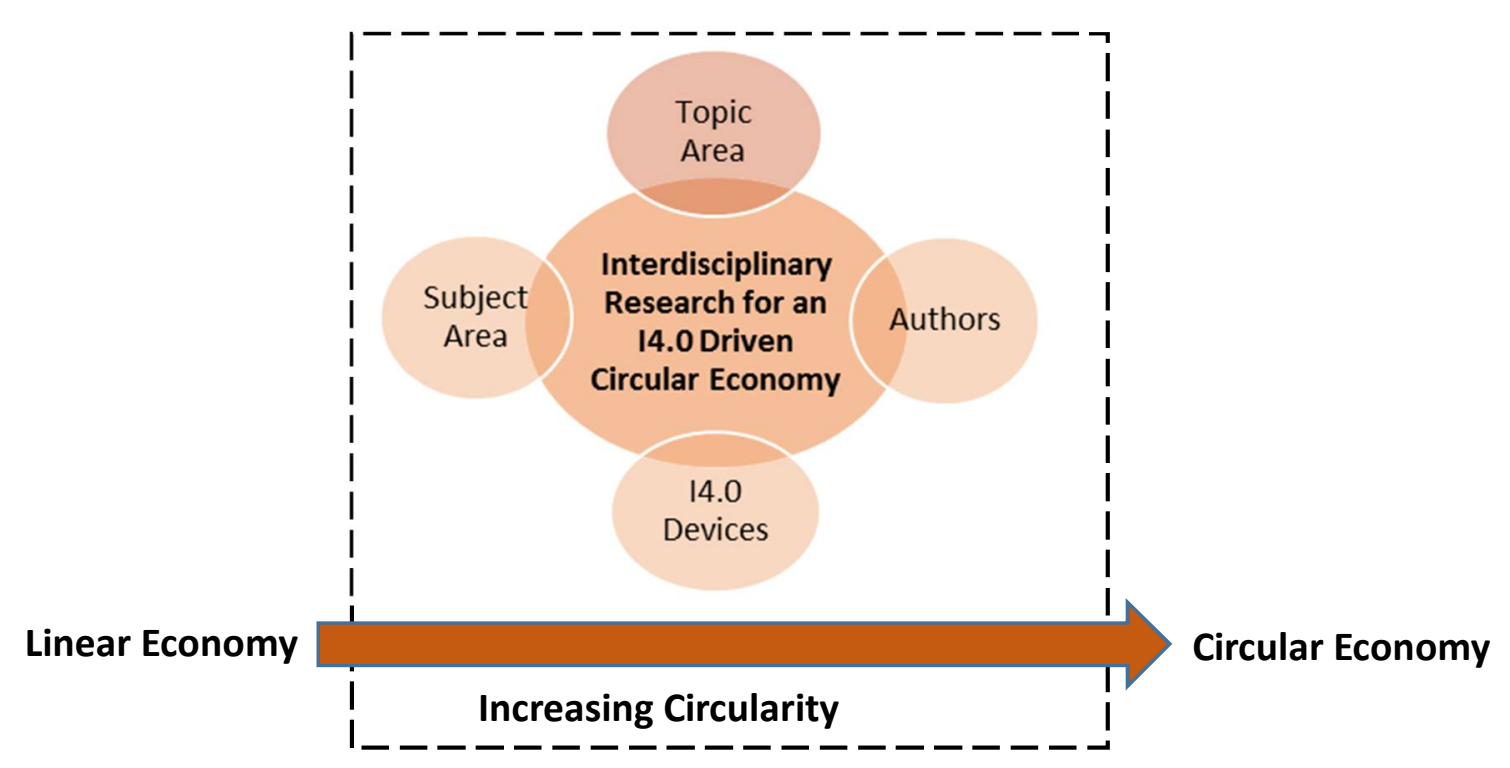

Figure 10: Multidisciplinarity in Industry 4.0 for a CE research

Interdisciplinary research has been observed to be a key ingredient in CE research. As observed in [17] and [69] implementation strategies, business modelling and policy making for CE must be multidisciplinary-driven for sustainable goals to be realized. Current CE research in dissemination of the $\mathrm{CE}$, according to [69] is being hampered by diverging approaches and there is little focus on multidisciplinarity in circularity implementation. There are other aspects of this research where multidiscplinarity has been seen to be important. Sheng et al, [68] argues the case of multidisciplinarity in big data research, as important in driving research. According to [68] a few scholars have suggested an integrated multidisciplinary approach in research and understanding of big data, for a more comprehensive research outcome. Multidisciplinarity has also been argued in research element involving the Internet of Things, or IoT. The Internet of Things is described by Atzori et al., [70] as a concept of billions of interconnected smart devices (sensors, controllers, machines, autonomous vehicles, etc) that allows any participatory object to be sensed and controlled remotely across existing network infrastructure. Thus unlimited opportunities are created through the automatic collection and exchange of data[71]. Two key contributions are highlighted in [66] 
which drives the multidisciplinarity of research in IoT. These includes the smart applications [72] and future IoT systems challenges [66].

Mulitidisciplinarity is evident in the outcome of this research. These include, in subject area which had 8 main subjects and 6 other sub areas, described in Figure 9 as "others". These includes "Physics", "Mathematics", "Earth and Planetary Science", "Economics", "Biochemistry" and "Agricultural Science". Topic areas considered under the 9R's also suggests a multidisciplinary content of the research. A cursory look at the subject areas suggests that research in using 14.0 and digital technologies to drive the $\mathrm{CE}$ is still domiciled within the engineering and sciences as only "Economics", and "Business \& Management" can be argued to be outside this category. This also suggests why over $50 \%$ of the authors across the selected articles are affiliated to institutions of technology.

\subsection{Industry 4.0 and Digital Technologies}

The $4^{\text {th }}$ Industrial Revolution or Industry 4.0, (also defined as smart manufacturing[35]), is a common feature from the systematic literature review. The main framework supporting I4.0 was first published by Kagermann in 2011 and thereafter by the German National Academy of Science in 2013, [73]. A simple definition for this is thus: "manufacturing systems driven by information technology", [74]. However, as I4.0 is based on three key paradigms of the Smart Product, the Smart Machine and the Augmented Operator [75] a concise definition becomes imperative. Thus, as elaborated in [35] I4.0 involves a "combination of smart factories and products and the Internet of Things that aims to provide real time information on production, machines and flow of components, integrating this information in order to help managers to make decisions, monitor performance and track parts and products, [76]. Table 6 gives an overview of the functional technologies encompassing Industry 4.0.

Table 6: Overview of the functional technologies of Industry 4.0. Adapted from Kang et al., [77]

\begin{tabular}{|c|c|c|}
\hline Technology & Description & Resources in use. \\
\hline Cyber-physical systems & $\begin{array}{l}\text { Enables automation, } \\
\text { monitoring and control of } \\
\text { processes and objects in real } \\
\text { time [78] }\end{array}$ & $\begin{array}{l}\text { Controllers and sensor systems } \\
\text { [78] \& [79] }\end{array}$ \\
\hline Cloud Manufacturing & $\begin{array}{l}\text { Virtual portals which create a } \\
\text { shared network of } \\
\text { manufacturing resources and } \\
\text { capabilities offered as services } \\
\text { [79] }\end{array}$ & The Internet \\
\hline Internet of Things (IoT) & $\begin{array}{l}\text { A computational system which } \\
\text { collects and exchanges data } \\
\text { acquired from electronic } \\
\text { devices[77] }\end{array}$ & $\begin{array}{l}\text { Radio-frequency identification } \\
\text { (RFID) technology tags, } \\
\text { sensors,barcodes, } \\
\text { smartphones [[80] \& [71] }\end{array}$ \\
\hline Additive Manufacturing & $\begin{array}{l}\text { Represents agile and } \\
\text { connected prototyping of parts } \\
\text { of products on a large scale, } \\
\text { enabling customization [81] }\end{array}$ & $3 \mathrm{D}$ printers \\
\hline
\end{tabular}

Thus, in addition to the key technologies of I4.0 identified in [77] we will list cyber-physical systems, cloud manufacturing, internet of things, big data, additive manufacturing, and big data as key technologies of I4.0. This research is developed from the argument that Industry 4.0 technologies, 
also referred to as "digital technologies", are able to enable circular approaches and hence, the circular economy. For example, tracking products post-production by the use of sensors in order to recover components[35] or inform end of life strategy [36]. As outlined in a research survey conducted by PWC on 235 German industrial companies, [82] while enabling products with digital devices requires considerable investments, there are clear economic potential for products postproduction and the larger circular economy. When companies from the following industries: manufacturing and engineering, automotive suppliers, process industry, electronics and electrical systems, information and communications, [82] were interviewed and the results analyzed it was concluded that, while the digitization of value chains were top priority for all companies irrespective of size, the benefits for the CE per company was a degree of the extent of digitization deployed on products. Mulitidisciplinarity is also a key driver for this. However, the relationship between circular approaches, industry 4.0 and the $\mathrm{CE}$ has not been widely explored in literature, due to the recent emergence of these ideas [35]. Also, as can be argued from this research, the complexity of multidisciplinarity and the difficulty in accessing industry data and analyzing big data [68] are obvious challenges in exploring this research.

To propose a framework for further research into this integrated we start by designing a table of selected circular approach from the 3R's of "Reuse", "Recycle" and "Remanufacturing" selected from the 174 papers. The reason for these choices were driven by availability of information for the headings chosen. The table was drawn according to these headings; "Authors", "Product Type", "Digital Technology Used", "Circular Approach", Year of Publication", "Name of Journal/Paper". From these, the following definitions are pertinent. Digital Technologies are defined as electronic tools, systems, devices and resources that generate, store or process data [83]. By "product type" we refer to the name of the product in which the digital technology is embedded. Hence, the focus for this table is on "Product Type", "Digital Technology" and "Circular Approach" highlighted in paper. We however provide other details for greater clarity. Table 7 indicates this grouping. 
Table 7: Selected papers highlighting Product Type, Digital Technology and Circular Approach

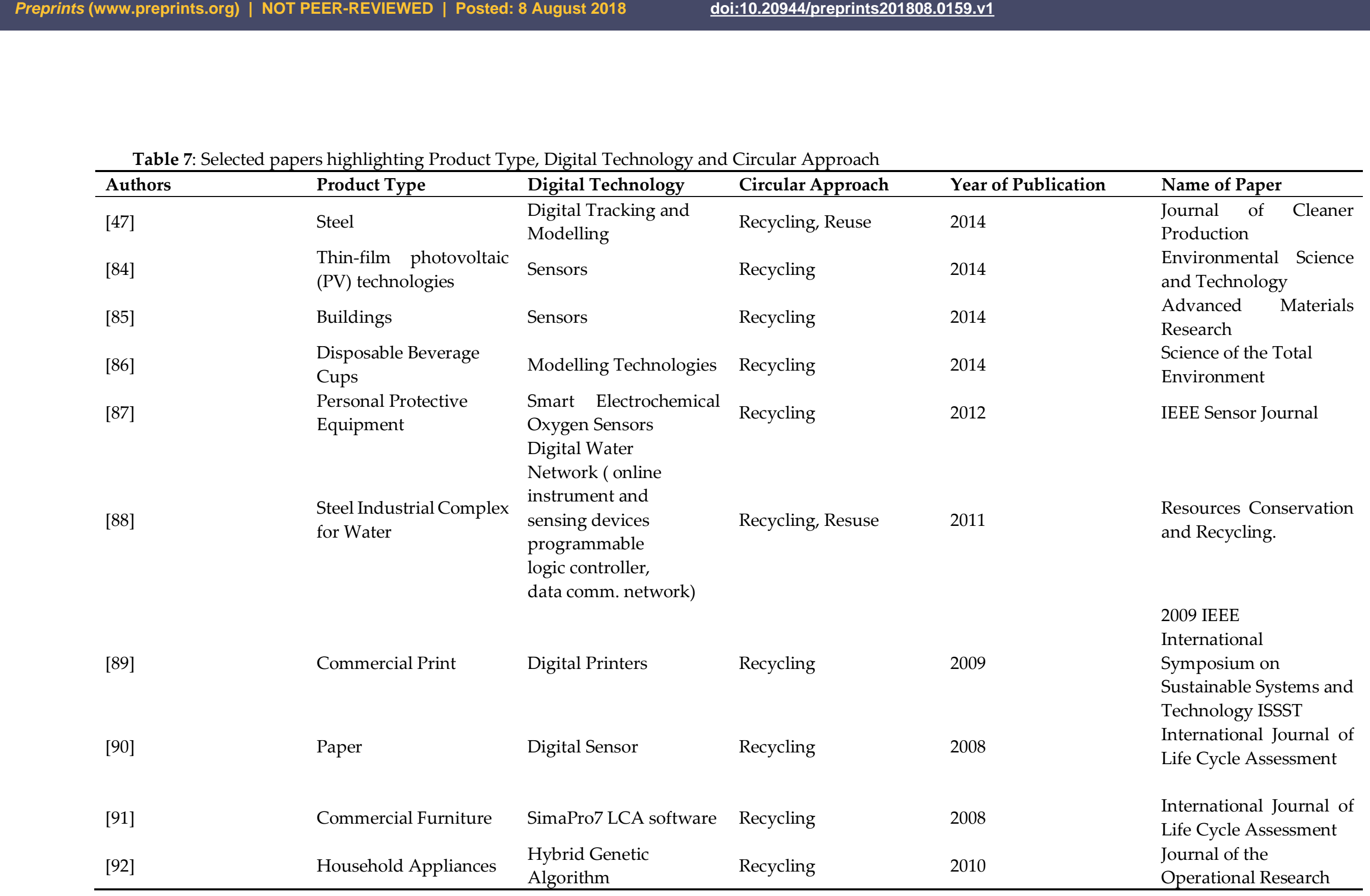




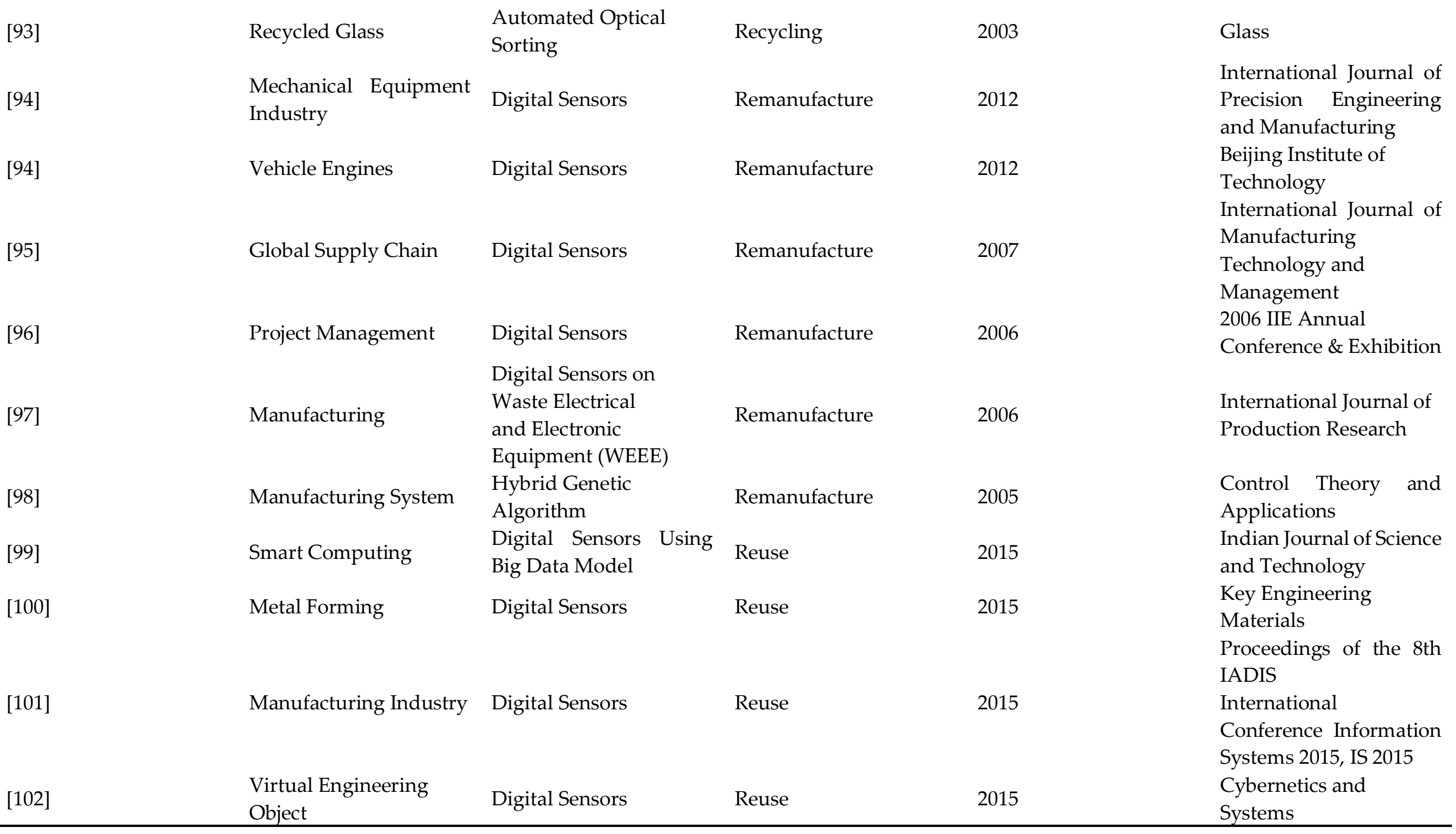




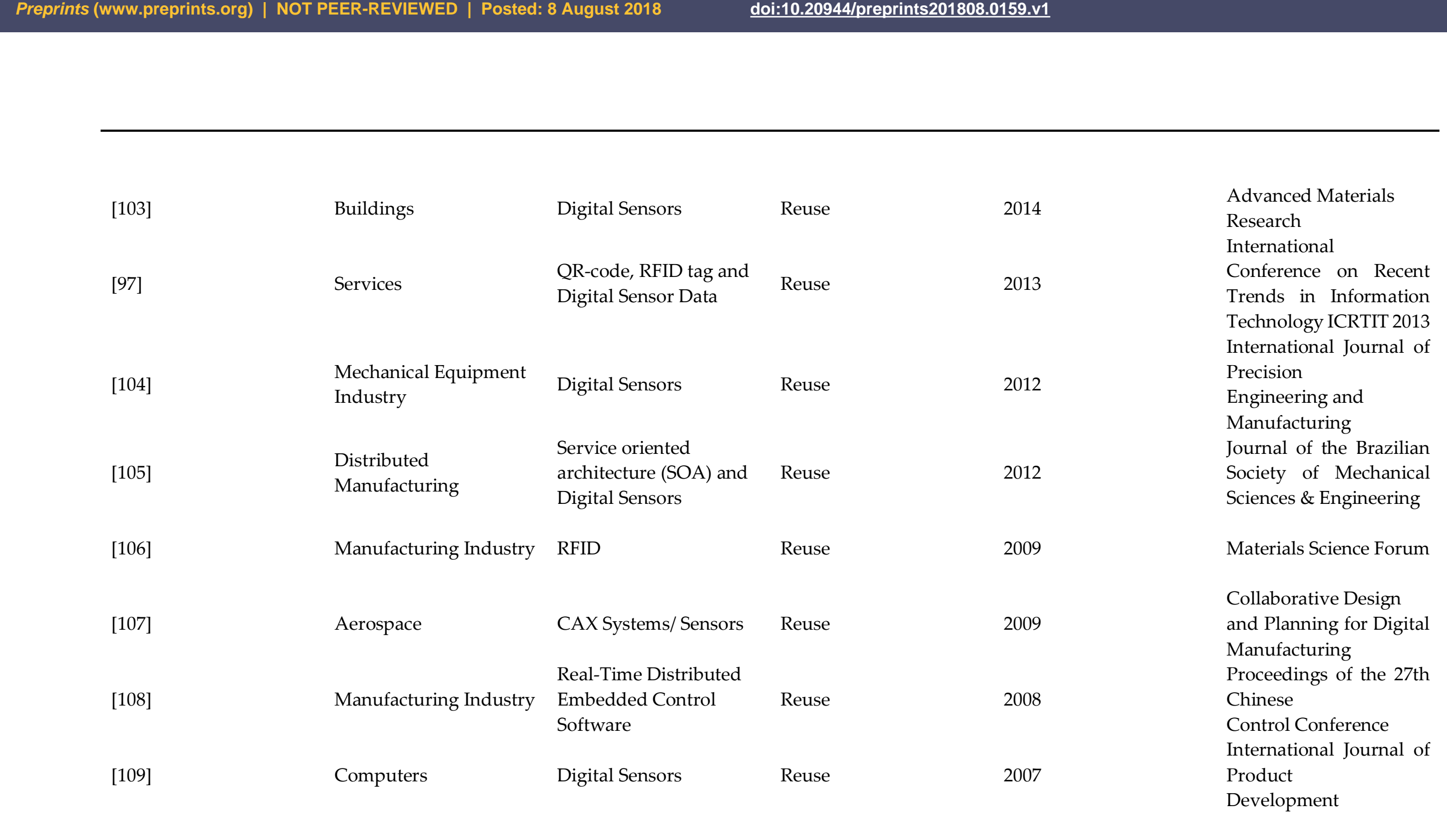




\begin{tabular}{|c|c|c|c|c|c|}
\hline [110] & Electronic Circuits & Automated Electronics & Reuse & 2005 & $\begin{array}{l}\text { IPC - Electronic Circuits } \\
\text { World Convention } \\
\text { Printed Circuits Expo, } \\
\text { Apex, and the Designers } \\
\text { Summit } 2005 \text {. }\end{array}$ \\
\hline [111] & Software Components & Digital Sensors & Reuse & 2002 & Computers in Industry \\
\hline [112] & Software Components & Digital Sensors & Reuse & 2000 & $\begin{array}{l}\text { Technology of Object- } \\
\text { Oriented Language and } \\
\text { Systems }\end{array}$ \\
\hline
\end{tabular}




\subsection{Framework for further Circular Economy-Circular Approaches-I4.0 Research}

From Table 7 a few relationships important to any framework becomes evident. Firstly, while digital technologies can enable circular approaches, these digital technologies are not specific to particular approaches. For example, "Digital Sensors", can be seen to be applicable in product "reuse"[97] "recycle"[90] and "remanufacture"[95]. Secondly, while "digital sensors" are highlighted in these papers with their equivalent circular approach, it must be noted that this does not offer much insight into what actual digital sensors was used. If the question asked by Saar and Thomas (2002), "what is the relation between environment and digital futures?" [113] is applied here, it will be important to know the specific digital sensor employed for enabling a circular approach. Papers such as [97] and [114] clearly state QR-code and RFID as specific digital sensors used to enable product reuse. In developing a framework for future research, it is thus important to understand digital sensors and key sensors employed for circular economy approach.

Radio Frequency Identification or RFID, is a digital tag device that has become almost ubiquitous in manufacturing and service delivery. It is a wireless technology which is capable of identifying objects in a way that is unique and automatic, [114]. It is employed in retail cloth and music stores, mail parcel services to airports. It is an upgrade from bar code, which required close proximity between the object and the bar code for it to function. Thus, [47] is a contactless technology that can operate without the line-of-sight restrictions in bar code. Modern RFID label may have extra features such as sensors, [113] which can have the capacity to monitor physical parameters such as pressure, humidity and temperature. The concept of RFID tagging and monitoring has been applied to promote lean construction in the construction industry [115], in the steel industry [47] and for computing, [116]. RFID has also been seen as a veritable tool in enabling business models and lifecycle of products, which includes steel, [47], while substantially improving reuse and resource efficiency. Thus in proposing an integrated framework for future research, we consider these key questions;

1. Questions on the Circular Economy

- What are existing research in relation to manufacturing?

- What are existing gaps in relation to enabling the CE for manufacturing?

- Has multidisciplinarity in research been considered?

2. Questions on the Circular Economy Approach

- What are the existing research in circular economy approach which relates to the specific manufacturing procedure?

- What are the existing research in circular economy approach which relates to the specific I4.0 paradigm?

3. Questions on the Digital Technologies to enable the CE

- What type of sensors is being used in the product?

- What particular end-of-life approach can that digital sensor help enable that product towards?

- Who are the stakeholders necessary to assist this integration

Figure $\mathbf{1 1}$ gives the suggested framework for future integrated research. 


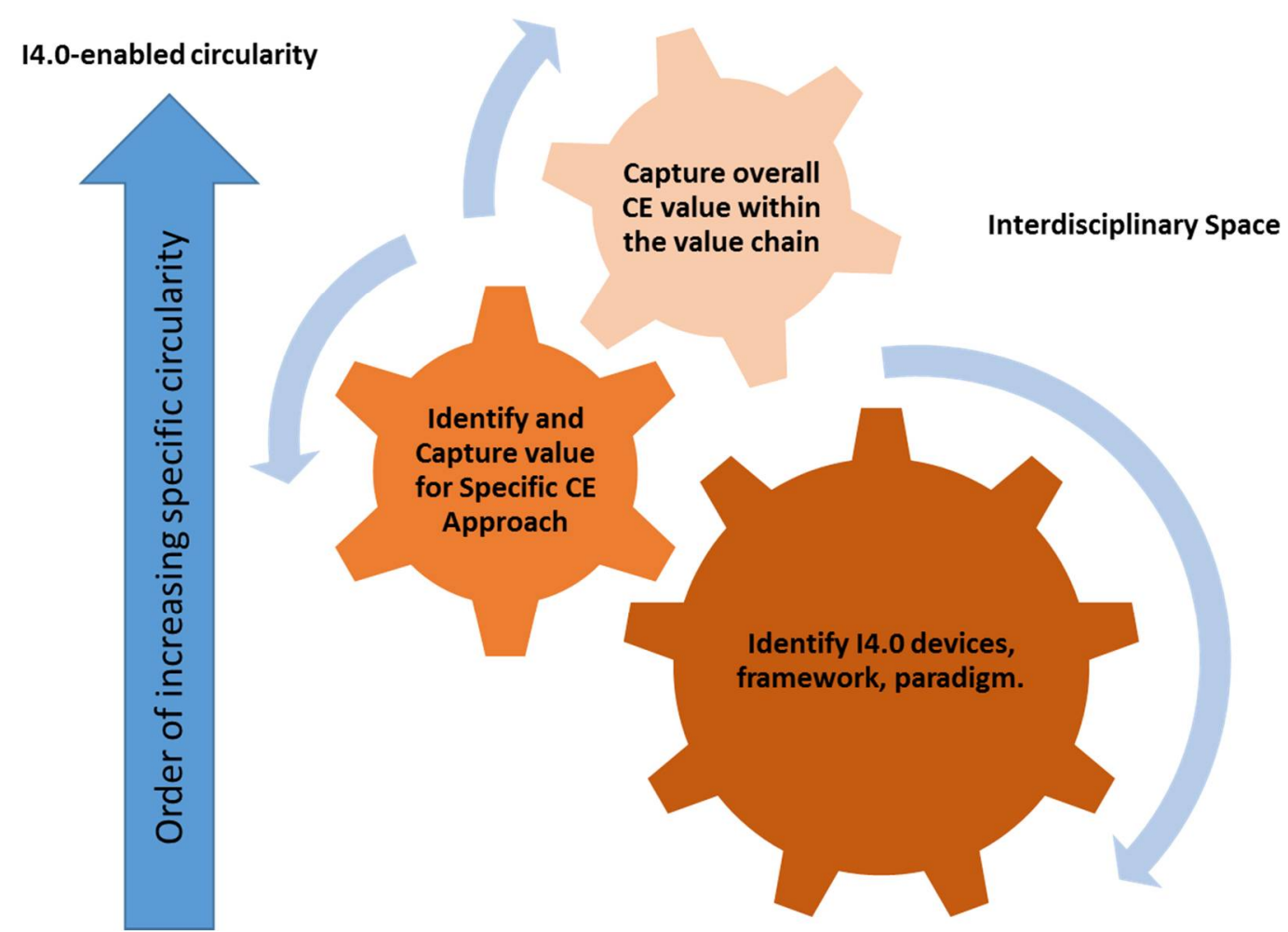

Figure 11: Framework for further integrated research

\subsection{Conclusion}

This work presents a systematic review of literature that integrates data-driven circular approaches with concepts of Industry 4.0. It investigates the development and current state of this research area; it also discusses some key aspects of this research area. Based on our review it can be concluded that;

(a) The most significant finding of this research is that research on the circular approaches and digital technologies do not currently integrate the circular approaches as concepts of the Circular Economy. It is suggested that there is urgent need for CE researchers, industry practitioners and policy-makers, therefore, to begin to see circular approaches as components and subsets of the circular economy instead of stand-alone concepts.

(b) Despite the amount of research on the Circular Economy and the interests from the academia, industry practitioners and policy-makers undertaken in recent years, CE research is still a relatively new area of research in sustainability research.

(c) Research multidisciplinarity increases circularity and brings greater visibility in circular approaches.

(d) Despite the pervasiveness of Industry 4.0 and Digital Technologies and the understanding of the digital technologies as key enablers of the $\mathrm{CE}$, there is little research on this important integration. Thus literature encountered were largely homogenous than heterogeneous in context. To tackle this gap and optimize the embedded benefits, researchers suggests the development of methodologies centered on the type of circular approach.

(e) Digital sensors were found to be the most common digital technology across a wide range of product type, uses and across circular approaches, more than other digital technology.

(f) Policy and managerial implications can be deduced from the review. The review suggests that there is need for greater involvement for industry practitioners if the 
benefits of data-driven circular approaches for digital technologies can be optimized. As there are more conference papers in this subject than journal papers, it is likely that further research in this area by academia is severely hampered by lack of data for research and lack of involvement by industry.

(g) Due to the various circular approaches in literature -the 3Rs, 4Rs, 6Rs and 9Rs -there is need to develop an acceptable definition for the $\mathrm{CE}$ as it relates to data-driven circular approaches. An acceptable definition would involve a collaboration between industry, academia and policymakers.

(h) There are various digital technologies currently in place which enables circular approaches and in turn, the Circular Economy. However, due to the pervasiveness of this technologies, there is difficulty in capturing and validating the value for the CE. To solve this challenge, useful categorizations are suggested. This should give more understanding of digital technologies and $\mathrm{CE}$, important for industry and policymakers.

(i) There is need to examine the various methodologies that drive the selection of circular approach to digital technology. We suggest that research on enabling methodologies should focus on a smaller scope of approaches (for example, 3R) and not a wider scope (for example 9R), for more detailed results.

(j) Digital technologies at the moment focuses on recycling, remanufacture and reuse as main circular approach enablers. Investigations are needed to examine why this is pervasive. Using reuse, remanufacture and recycling, further methodologies can be developed which develop further methodologies which can be utilized to Recycling, Remanufacture and Reuse as circular approach forms the most common research which

(k) The framework suggested for further integrated research is a generic framework. For future research, we suggest the development of theoretical frameworks that focus on specific circular approaches or smaller scope of approaches (such as 3R).

\section{Acknowledgement:}

This research has been partially funded by EPSRRC Network Plus Connected Everything of which the authors expresses their gratitude.

\section{REFERENCES}

1. Sachs J. The Age of Sustainable Development. Columbia University Press; 2015.

2. Geissdoerfer M., Savaget P., Bocken NMP., Hultink EJ. Review: The Circular Economy - A new sustainability paradigm? Journal of Cleaner Production. 2017; 143(January): 757-768. Available at: DOI:10.1016/j.jclepro.2016.12.048.CITATION

3. Meadows, D.H., Randers, J., Meadows DL. The Limits to Growth. The 30-year Update. London: Routledge; 2009.

4. Jackson T. Prosperity without Growth. Economics for a Finite Planet. London, New York: Earthscan; 2009.

5. Banerjee, A., Duflo E. Poor Economics: A Radical Rethinking of the Way to Fight Global Poverty. 2011.

6. Clark WC., Crutzen PJ., Schellnhuber HJ. Science for Global Sustainability: Toward a New Paradigm. CID Working Paper No.120. 2005. Available at: http://www.cid.harvard.edu/cidwp/120.htm

7. Rockstrom, J., Steffen, W., Noone, K., Persson, A., Chapin III, F.S., Lambin, E., Lenton, T.M., 
Scheffer, M., Folke, C., Schellnhuber, H., Nykvist, B., De Wit, C.A., Hughes, T., van der Leeuw, S., Rodhe, H., Sorlin, S., Snyder, P.K., Costanza, R., Svedin, 32. [online] URL. Planetary boundaries: exploring the safe operating space for humanity. Ecology and Society.

8. Esposito M., Tse T., Soufani K. Introducing a Circular Economy: New Thinking with New Managerial and Policy Implications. California Management Review. 2018; : 5-19. Available at: DOI:10.1177/0008125618764691

9. Sauvé S., Bernard S., Sloan P. Environmental Sciences, Sustainable Development and Circular Economy.Pdf. 2016; 17: 48-56.

10. A. Siegel, R. Bautista and JP. Retail Horizons: Envisioning the Future of the Retail Industry. Forum for the Future and Retail Industry Leaders Association. 2014.

11. Kirchherr J., Reike D., Hekkert M. Conceptualizing the Circular Economy: An Analysis of 114 Definitions. Resources, Conservation and Recycling. 2017; 127(September): 221-232. Available at: DOI:10.1016/j.resconrec.2017.09.005

12. de Vries BJM., Petersen AC. Conceptualizing sustainable development. An assessment methodology connecting values, knowledge, worldviews and scenarios. Ecological Economics. Elsevier B.V.; 2009; 68(4): 1006-1019. Available at: DOI:10.1016/j.ecolecon.2008.11.015

13. Gladek E. The Seven Pillars of the Circular Economy. 2017.

14. Lieder M., Rashid A. Towards circular economy implementation: A comprehensive review in context of manufacturing industry. Journal of Cleaner Production. Elsevier Ltd; 2016; 115: 3651. Available at: DOI:10.1016/j.jclepro.2015.12.042

15. Blomsma F., Brennan G. The Emergence of Circular Economy: A New Framing Around Prolonging Resource Productivity. Journal of Industrial Ecology. 2017; 21(3): 603-614. Available at: DOI:10.1111/jiec.12603

16. Ghisellini P., Cialani C., Ulgiati S. A review on circular economy: The expected transition to a balanced interplay of environmental and economic systems. Journal of Cleaner Production. September 2015; 114: 11-32. Available at: DOI:10.1016/j.jclepro.2015.09.007 (Accessed: 17 September 2015)

17. Murray A., Skene K., Haynes K. The Circular Economy: An Interdisciplinary Exploration of the Concept and Application in a Global Context. Journal of Business Ethics. Springer Netherlands; 2017; 140(3): 369-380. Available at: DOI:10.1007/s10551-015-2693-2

18. Lieder M., Asif FMA., Rashid A. Towards Circular Economy implementation: an agent-based simulation approach for business model changes. Autonomous Agents and Multi-Agent Systems. Springer US; 2017; : 1377-1402. Available at: DOI:10.1007/s10458-017-9365-9

19. Yuan Zengwei, Bi Jun MY. The Circular Economy A New Development Strategy in China. Industrial Ecology in Asia. 2006; 10: 1-2. Available at: DOI:10.1038/531435a

20. Ormazabal M., Prieto-Sandoval V., Puga-Leal R., Jaca C. Circular Economy in Spanish SMEs: Challenges and opportunities. Journal of Cleaner Production. 2018; 185: 157-167. Available at: DOI:10.1016/j.jclepro.2018.03.031

21. Nobre GC., Tavares E. Scientific literature analysis on big data and internet of things applications on circular economy: a bibliometric study. Scientometrics. Springer Netherlands; 2017; 111(1): 463-492. Available at: DOI:10.1007/s11192-017-2281-6

22. Merli R., Preziosi M., Acampora A. How do scholars approach the circular economy? Journal of Cleaner Production. 2018; 178. 
23. Pearce, David and Turner K. Economics of Natural Resources and the Environment. Johns Hopkins University Press, 1990; 1990. 378 p. Available at: https://books.google.co.uk/books/about/Economics_of_Natural_Resources_and_the_E.html? id=ex8vaG6m4RMC\&redir_esc=y

24. Lewandowski M. Designing the business models for circular economy-towards the conceptual framework. Sustainability (Switzerland). 2016; 8(1): 1-28. Available at: DOI:10.3390/su8010043

25. Su B., Heshmati A., Geng Y., Yu X. A review of the circular economy in China: Moving from rhetoric to implementation. Journal of Cleaner Production. Elsevier Ltd; 2013; 42: 215-227. Available at: DOI:10.1016/j.jclepro.2012.11.020

26. Masi D., Day S., Godsell J. Supply Chain Configurations in the Circular Economy: A Systematic Literature Review. Sustainability. 2017; 9(9): 1602. Available at: DOI:10.3390/su9091602

27. Lacy P., Rutqvist J. Waste to wealth. 2016; : 159. Available at: DOI:10.1007/s13398-014-0173-7.2

28. Lund RT and BM. Remanufacturing: The experience of the United States and implications for developing countries. 1984; (31): 126. Available at: http://documents.worldbank.org/curated/en/792491468142480141/Remanufacturing-theexperience-of-the-United-States-and-implications-for-developing-countries

29. Prieto-Sandoval V., Jaca C., Ormazabal M. Towards a consensus on the circular economy. Journal of Cleaner Production. Elsevier Ltd; 2018; 179: 605-615. Available at: DOI:10.1016/j.jclepro.2017.12.224

30. Ellen MacArthur Foundation. Towards the Circular Economy: Economic and business rationale for an accelerated transition. 2013. Available at: DOI:10.1007/b116400

31. Bocken NMP., de Pauw I., Bakker C., van der Grinten B. Product design and business model strategies for a circular economy. Journal of Industrial and Production Engineering. Taylor \& Francis; 2016; 33(5): 308-320. Available at: DOI:10.1080/21681015.2016.1172124

32. Reike D., Vermeulen WJV., Witjes S. The circular economy: New or Refurbished as CE 3.0? Exploring Controversies in the Conceptualization of the Circular Economy through a Focus on History and Resource Value Retention Options. Resources, Conservation and Recycling. Elsevier; 2017; 135(February 2017): 246-264. Available at: DOI:10.1016/j.resconrec.2017.08.027

33. Antikainen M., Uusitalo T., Kivikytö-Reponen P. Digitalisation as an Enabler of Circular Economy. Procedia CIRP. Elsevier B.V.; 2018; 73: 45-49. Available at: DOI:10.1016/j.procir.2018.04.027

34. Stankovic M, Gupta R FJI. Industry 4.0 - Opportunities behind the challenge. UNIDO Background paper. 2017. Available at: https://www.unido.org/gc17/industry40 (Accessed: 7 August 2018)

35. Beatriz A., Sousa L De., Charbel J., Chiappetta J., Godinho M., David F. Industry 4.0 and the circular economy: a proposed research agenda and original roadmap for sustainable operations. Annals of Operations Research. Springer US; 2018; Available at: DOI:10.1007/s10479-018-2772-8

36. O. Okorie, C. Turner, F. Charnley, M. Moreno AT. A review of data driven approaches for Circular Economy in manufacturing. 18th European Roundtable for Sustainable Consumption and Production, ERSCP. Skiathos Island, Greece: 18th European Roundtable for Sustainable Consumption and Production, ERSCP.; 2017. pp. 120-131. 
37. Ellen Macarthur Foundation. INTELLIGENT ASSETS : UNLOCKING THE CIRCULAR ECONOMY POTENTIAL. 2016.

38. Dustin Benton EC and JH. A circular economy for smart devices. 2015. Available at: http://www.green-alliance.org.uk/resources/A circular economy for smart devices.pdf

39. Tranfield D., Denyer D., Smart P. Towards a Methodology for Developing Evidence-Informed Management Knowledge by Means of Systematic Review Towards a Methodology for Developing Evidence-Informed Management Knowledge by Means of Systematic Review * 2003; 14(September 2016): 207-222. Available at: DOI:10.1111/1467-8551.00375

40. Short J. The Art of Writing a Review Article. 2009; Available at: DOI:10.1177/0149206309337489

41. Ruschel E., Alves E., Santos P., Freitas E De., Loures R. Industrial maintenance decisionmaking : A systematic literature review. 2017; 45: 180-194.

42. Thelwall M. Dimensions : A competitor to Scopus and the Web of Science ? Journal of Informetrics. Elsevier Ltd; 2018; 12(2): 430-435. Available at: DOI:10.1016/j.joi.2018.03.006

43. Mongeon P. The journal coverage of Web of Science and Scopus : 2016; : 213-228. Available at: DOI:10.1007/s11192-015-1765-5

44. Waltman L., Eck NJ Van., Leeuwen TN Van., Visser MS., Raan AFJ Van. Towards a new crown indicator : Some theoretical considerations. Journal of Informetrics. Elsevier Ltd; 2011; 5(1): 37-47. Available at: DOI:10.1016/j.joi.2010.08.001

45. Tseng ML., Tan RR., Chiu ASF., Chien CF., Kuo TC. Circular economy meets industry 4.0: Can big data drive industrial symbiosis? Resources, Conservation and Recycling. Elsevier; 2018; 131(January): 146-147. Available at: DOI:10.1016/j.resconrec.2017.12.028

46. Qiao F., Qiao N. Circular economy: An ethical and sustainable economic development model. Prakseologia. 2013; (154): 253-272. Available at: http://www.scopus.com/inward/record.url?eid=2-s2.084888191662\&partnerID=40\&md5=0b6931630c17aa04e5edd88065320dfb

47. Ness D., Swift J., Ranasinghe DC., Xing K., Soebarto V. Smart steel: New paradigms for the reuse of steel enabled by digital tracking and modelling. Journal of Cleaner Production. Elsevier Ltd; 2015; 98: 292-303. Available at: DOI:10.1016/j.jclepro.2014.08.055

48. Joshi K, Venkatachalam A JI. A new methodology for transforming 3R concept into 6R concept for improved product sustainability. Proceedings of the IV global conference on sustainable product development and life cycle engineering. Sao Carlos; 2006.

49. Potting J., Hekkert M., Worrell E., Hanemaaijer A. CIRCULAR ECONOMY : MEASURING INNOVATION IN THE Policy Report. 2017; (January).

50. van Buren N., Demmers M., van der Heijden R., Witlox F. Towards a circular economy: The role of Dutch logistics industries and governments. Sustainability (Switzerland). 2016; 8(7): 117. Available at: DOI:10.3390/su8070647

51. Podsakoff PM., Mackenzie SB., Bachrach DG., Podsakoff NP. The influence of management journals in the 1980s and 1990s. Strategic Management Journal. 2005; 26(5): 473-488. Available at: DOI:10.1002/smj.454

52. Pittaway L., Robertson M., Munir K., Denyer D., Neely A. Networking and innovation: a systematic review of the evidence 200. International Journal of Management Reviews. 2004; 5-6(3-4): 137-168. Available at: DOI:10.1111/j.1460-8545.2004.00101.x

53. Roehrich JK., Lewis MA., George G. Are public-private partnerships a healthy option? A 
systematic literature review. Social Science and Medicine. Elsevier Ltd; 2014; 113: 110-119. Available at: DOI:10.1016/j.socscimed.2014.03.037

54. Cerchione R., Esposito E. A systematic review of supply chain knowledge management research: State of the art and research opportunities. International Journal of Production Economics. Elsevier; 2016; 182: 276-292. Available at: DOI:10.1016/j.ijpe.2016.09.006

55. Schulze M., Nehler H., Ottosson M., Thollander P. Energy management in industry - A systematic review of previous findings and an integrative conceptual framework. Journal of Cleaner Production. Elsevier Ltd; 2016; 112: 3692-3708. Available at: DOI:10.1016/j.jclepro.2015.06.060

56. Moreno M., Braithwaite N., Cooper T. Moving beyond the circular economy. In: MORENO, M.A., BRAITHWAITE, N. and COOPER T (ed.) Proceedings of Going Green - CARE INNOVATION 2014., Going Green - CARE INNOVATION 2014, Schoenbrunn Palace Conference Centre, Vienna, Austria, 17-20 November 2014. Vienna, Austria.: Nottingham Trent University; 2014. pp. 1-10. Available at: http://www.researchgate.net/publication/281115672

57. S GF., Zhang K. Evaluation of most Suitable Electronic Waste Recycling Components from Economic and Environmental Point of View. Interdisciplinary Journal of Reserach in Business. 2012; 1: 1-10.

58. Roets L., Botma Y. Challenges and opportunities nurses experienced to turn conference presentations into journal articles. International Journal of Africa Nursing Sciences. Elsevier; 2018; 9(May): 9-13. Available at: DOI:10.1016/j.ijans.2018.06.002

59. Zhang L., Glänzel W. Proceeding papers in journals versus the ' regular' journal publications. Journal of Informetrics. 2012; 6(1): 88-96. Available at: DOI:10.1016/j.joi.2011.06.007

60. Geng Y., Doberstein B. Developing the circular economy in China: Challenges and opportunities for achieving'leapfrog development'. International Journal of Sustainable Development \& World Ecology. 2008; 15(April 2016): 231-239. Available at: DOI:10.3843/SusDev.15.3

61. Hauser W., Lund R. The Remanufacturing Industry: Anatomy of a Giant, Report. Boston; 2008. Available at: http://www.bu.edu/reman/OrderAnatomy.htm

62. Epsrc CE. Manufacturing a Circular Economy A position statement on circular economy research in the UK. 2015; (December): 1-19.

63. Commission E. Circular Economy Package: Questions \& Answers. European Commission. 2015. Available at: http://europa.eu/rapid/press-release_MEMO-15-6204_en.htm (Accessed: 12 July 2018)

64. König B., Diehl K., Tscherning K., Helming K. A framework for structuring interdisciplinary research management. Research Policy. 2013; 42(1): 261-272. Available at: DOI:http://dx.doi.org/10.1016/j.respol.2012.05.006

65. Thompson Klein J. Prospects for transdisciplinarity. Futures. 2004; 36(4): 515-526. Available at: DOI:10.1016/j.futures.2003.10.007

66. López-Benítez M., Drysdale TD., Hadfield S., Maricar MI. Prototype for multidisciplinary research in the context of the Internet of Things. Journal of Network and Computer Applications. 2017; 78(November 2016): 146-161. Available at: DOI:10.1016/j.jnca.2016.11.023

67. Huutoniemi K., Thompson J., Bruun H., Hukkinen J. Analyzing interdisciplinarity : Typology and indicators. 2010; 39: 79-88. Available at: DOI:10.1016/j.respol.2009.09.011 
68. Sheng J., Amankwah-Amoah J., Wang X. A multidisciplinary perspective of big data in management research. International Journal of Production Economics. 2017; 191(November 2016): 97-112. Available at: DOI:10.1016/j.ijpe.2017.06.006

69. Kalmykova Y., Sadagopan M., Rosado L. Circular economy - From review of theories and practices to development of implementation tools. Resources, Conservation and Recycling. Elsevier; 2017; 135(February 2017): 190-201. Available at: DOI:10.1016/j.resconrec.2017.10.034

70. Atzori L., Iera A., Morabito G. The Internet of Things: A survey. Computer Networks. Elsevier B.V.; 2010; 54(15): 2787-2805. Available at: DOI:10.1016/j.comnet.2010.05.010

71. Atzori L., Iera A., Morabito G. From 'smart objects' to 'social objects': The next evolutionary step of the internet of things. IEEE Communications Magazine. 2014; 52(1): 97-105. Available at: DOI:10.1109/MCOM.2014.6710070

72. Zanella a., Bui N., Castellani a., Vangelista L., Zorzi M. Internet of Things for Smart Cities. IEEE Internet of Things Journal. 2014; 1(1): 22-32. Available at: DOI:10.1109/JIOT.2014.2306328

73. Stock T., Seliger G. Opportunities of Sustainable Manufacturing in Industry 4.0. Procedia CIRP. 2016; 40: 536-541. Available at: DOI:10.1016/j.procir.2016.01.129 (Accessed: 22 February 2016)

74. Lasi, H., Fettke, P., Kemper, H. G., Feld, T., \& Hoffmann M. Industry 4.0. Business \& Information Systems Engineering. 2014; 6(4): 239-242.

75. Weyer S., Schmitt M., Ohmer M., Gorecky D. Towards Industry 4.0 - Standardization as the crucial challenge for highly modular, multi-vendor production systems. IFAC-PapersOnLine. 2015; 48(3): 579-584. Available at: DOI:10.1016/j.ifacol.2015.06.143 (Accessed: 16 November 2015)

76. Lu Y. Industry 4.0: A survey on technologies, applications and open research issues. Journal of Industrial Information Integration. Elsevier Inc.; 2017; 6: 1-10. Available at: DOI:10.1016/j.jii.2017.04.005

77. Kang HS., Lee JY., Choi S., Kim H., Park JH., Son JY., et al. Smart manufacturing: Past research, present findings, and future directions. International Journal of Precision Engineering and Manufacturing - Green Technology. 2016; 3(1): 111-128. Available at: DOI:10.1007/s40684-0160015-5

78. Wang L., TÃ Irngren M., Onori M. Current status and advancement of cyber-physical systems in manufacturing. Journal of Manufacturing Systems. The Society of Manufacturing Engineers; 2015; 37: 517-527. Available at: DOI:10.1016/j.jmsy.2015.04.008

79. Yu C., Xu X., Lu Y. Computer-Integrated Manufacturing, Cyber-Physical Systems and Cloud Manufacturing - Concepts and relationships. Manufacturing Letters. Society of Manufacturing Engineers (SME); 2015; 6: 5-9. Available at: DOI:10.1016/j.mfglet.2015.11.005

80. Xu L Da., He W., Li S. Internet of things in industries: A survey. IEEE Transactions on Industrial Informatics. 2014; 10(4): 2233-2243. Available at: DOI:10.1109/TII.2014.2300753

81. Holmström J., Holweg M., Khajavi SH., Partanen J. The direct digital manufacturing (r)evolution: definition of a research agenda. Operations Management Research. Operations Management Research; 2016; 9(1-2): 1-10. Available at: DOI:10.1007/s12063-016-0106-z

82. Koch V., Kuge S., Geissbauer R., Schrauf S. Industry 4.0 - Opportunities and challenges of the industrial internet. strategy\& Formerly Booz \& Company, PwC. 2014; 13: 1-51.

83. Laurillard D. Digital technologies and their role in achieving our ambitions for education. Analysis. 2008; : 1-40. Available at: http://eprints.ioe.ac.uk/628/ 
84. Bergesen JD., Heath GA., Gibon T., Suh S. Thin-film photovoltaic power generation offers decreasing greenhouse gas emissions and increasing environmental co-benefits in the long term. Environmental Science and Technology. 2014; 48(16): 9834-9843. Available at: DOI:10.1021/es405539z

85. Penglin Li LW and BZ. No Title. Advanced Materials Research. 2014; 926-930: 653-656. Available at: DOI:10.4028/www.scientific.net/AMR.926-930.653

86. van der Harst E., Potting J., Kroeze C. Multiple data sets and modelling choices in a comparative LCA of disposable beverage cups. Science of the Total Environment. Elsevier B.V.; 2014; 494-495: 129-143. Available at: DOI:10.1016/j.scitotenv.2014.06.084

87. Sieber A., Enoksson P., Krozer A. Smart electrochemical oxygen sensor for personal protective equipment. IEEE Sensors Journal. 2012; 12(6): 1846-1852. Available at: DOI:10.1109/JSEN.2011.2178593

88. Wang J., Li S., Xiong G., Cang D. Application of digital technologies about water network in steel industry. Resources, Conservation and Recycling. Elsevier B.V.; 2011; 55(8): 755-759. Available at: DOI:10.1016/j.resconrec.2010.12.011

89. Canonico S., Sellman R., Preist C. Reducing the greenhouse gas emissions of commercial print with digital technologies. Sustainable Systems and Technology, 2009. ISSST'09. IEEE International Symposium on. 2009; : 1-6. Available at: http://ieeexplore.ieee.org/xpls/abs_all.jsp?arnumber=5156685

90. Merrild H., Damgaard A., Christensen TH. Life cycle assessment of waste paper management: The importance of technology data and system boundaries in assessing recycling and incineration. Resources, Conservation and Recycling. 2008; 52(12): 1391-1398. Available at: DOI:10.1016/j.resconrec.2008.08.004

91. Babarenda Gamage G., Boyle C., McLaren SJ., McLaren J. Life cycle assessment of commercial furniture: A case study of Formway LIFE chair. International Journal of Life Cycle Assessment. 2008; 13(5): 401-411. Available at: DOI:10.1007/s11367-008-0002-3

92. Chu LK., Shi Y., Lin S., Sculli D., Ni J. Fuzzy chance-constrained programming model for a multi-echelon reverse logistics network for household appliances. Journal of the Operational Research Society. 2010; 61(4): 551-560. Available at: DOI:10.1057/jors.2008.162

93. Hottenstein F. DIGITAL TECHNOLOGIES FOR AUTOMATED OPTICAL SORTING OF RECYCLED GLASS. Glass. 2003; 80(8): 260.

94. Shan Z., Qin S., Liu Q., Liu F. Key manufacturing technology \& equipment for energy saving and emissions reduction in mechanical equipment industry. International Journal of Precision Engineering and Manufacturing. 2012; 13(7): 1095-1100. Available at: DOI:10.1007/s12541012-0143-y

95. Jarrod Goentzel, Lou Manzione, Richard Pibernik, Joseph Pruett BT. Strategic deployment of specialised testing and remanufacturing in a global high-tech supply chain. International Journal of Manufacturing Technology and Management (IJMTM). 2007; 11(1): 28-52. Available at: DOI:10.1504/IJMTM.2007.012445

96. Davis L., Samanlioglu F., Stanfield P., Davis JL., Carolina N. Systemized Critical Chain Project Management with Application to Remanufacturing. IIE Annual Conference. Proceedings. Norcross: Institute of Industrial and Systems Engineers (IISE); 2006. pp. 1-6. Available at: DOI:192460642

97. H.C.W. Lau, C.X.H. Tang, C.K.M. Lee GTSH. A generic object-based support system for 
manufacturing processes. International Journal of Product Development. 2007; 4(3-4). Available at: DOI:DOI: 10.1504/IJPD.2007.012502

98. Gu Qiaolun JJ. Fuzzy chance-constrained programming model for the integrated logistics network of remanufacturing/manufacturing system. Control Theory and Applications. 2005; 22(6). Available at: https://www.researchgate.net/publication/265983215_Fuzzy_chanceconstrained_programming_model_for_the_integrated_logistics_network_of_remanufacturin gmanufacturing_system

99. Rana A., Lehal GS. Smart Computing Prototype for Industry 4.0 Revolution with IOT and Bigdata Implementation Model. 2015; 8(December): 1-7. Available at: DOI:10.17485/ijst/2015/v8i35/8

100. Rojek G., Regulski K., Wilk-Kołodziejczyk D., Kluska-Nawarecka S., Jakowiec K., SmolarekGrzyb A. Methods of Computational Intelligence in the Context of Quality Assurance in Foundry Products. Archives of Foundry Engineering. 2016; 16(2): 11-16. Available at: DOI:10.1515/afe-2016-0018

101. Kern H., Stefan F., Fähnrich KP., Dimitrieski V. A mapping-based framework for the integration of machine data and information systems. Proceedings of the 8th IADIS International Conference Information Systems 2015, IS 2015. 2015; (October 2016): 113-120. Available at: http://www.scopus.com/inward/record.url?eid=2-s2.084944145438\&partnerID=tZOtx3y1

102. Shafiq SI., Sanin C., Toro C., Szczerbicki E. Virtual Engineering Object (VEO): toward experience-based design and manufacturing for industry 4.0. Cybernetics and Systems. 2015; 2015; 46(1-2): 35-50. Available at: DOI:10.1080/01969722.2015.1007734

103. Peng Lin Li, Li Jun Wu BZ. The Application of Digital Technology in the Recycling of Old Industrial Buildings. In: Peilong Xu, Hongzong Si YW and PW (ed.) Advanced Materials Research. 2014. pp. 653-656. Available at: DOI:10.4028/www.scientific.net/AMR.926-930.653

104. Shan, Z., Qin, S., Liu, Q. and Liu F. Key manufacturing technology \& equipment for energy saving and emissions reduction in mechanical equipment industry. International Journal of Precision Engineering and Manufacturing. 2012; 13(7): 1095-1100. Available at: DOI:10.1007/s12541-012-0143-y

105. Schützer, K., Moura, A. Á. de A., Anderl, R. and Mosch C. A web service application to support distributed manufacturing. Journal of the Brazilian Society of Mechanical Sciences and Engineering. 2012; 34(2): 120-125. Available at: DOI:10.1590/S1678-58782012000200003

106. Huang, George Q. Zhang, Y., Dai, Q.Y., Ho, O., Xu FJ. Agent-based workflow management for RFID-enabled real-time reconfigurable manufacturing. Collaborative Design and Planning for Digital Manufacturing. London: Springer London; 2009. pp. 341-364. Available at: DOI:10.1007/978-1-84882-287-0_14

107. Li, W., Guo, C.F., Tang XQ. Research on the integrated system of digital design/manufacturing/ management in aeroplane process equipments. Materials Science Forum. 2009; 1: 626-627. Available at: DOI:10.4028/www.scientific.net/MSF.626-627.635

108. Jing Z., Jianping W., Guo Z., Yunsheng Z. Service-oriented design and implementation strategy of real-time distributed embedded control software. Control Conference, 2008. CCC 2008. 27th Chinese. 2008; : 393-397. Available at: DOI:10.1109/CHICC.2008.4605508

109. H.C.W. Lau, C.X.H. Tang, C.K.M. Lee GTSH. A generic object-based support system for manufacturing processes. International Journal of Product Development. 2007; 4(3-4). 
Available at: DOI:10.1504/IJPD.2007.012502

110. Watson L. An Open standards based approach to the exchange of data in an automated electronics assembly operation. Electronic Circuits World Convention, Printed Circuits Expo, Apex, and the Designers Summit 2005: The Perfect Fit, ECWC 10; Anaheim, CA; United States; 22 February 2005 through 24 February 2005; Code 93729. IPC - Electronic Circuits World Convention, Printed Circuits Expo, Apex, and the Designers Summit 2005, ECWC 10: The Perfect Fit; 2005. pp. 1056-1057.

111. Worley JH., Castillo GR., Geneste L., Grabot B. Adding decision support to workflow systems by reusable standard software components. Computers in Industry. 2002; 49(1): 123-140. Available at: DOI:10.1016/S0166-3615(02)00063-5

112. Lee, S.P., Thin, S.K., Liu HS. Object-oriented manufacturing application framework. Technology of Object-Oriented Languages and Systems. IEEE Computer Society; 2000. pp. 253-262. Available at: DOI:10.1016/S0378-1119(00)00031-7

113. Saar S., Thomas V. Toward Trash That Thinks. Journal of Industrial Ecology. 2002; 6(2): 133146.

114. Huang GQ., Zhang Y., Dai QY., Ho O., Xu FJ. Agent-based workflow management for RFIDenabled real-time reconfigurable manufacturing. Collaborative Design and Planning for Digital Manufacturing. 2009; 23(2): 341-364. Available at: DOI:10.1007/978-1-84882-287-0_14

115. Taylor M. Radio frequency identification (RFID) and the lean construction process. In: Proc. 18th CIB World Congress 2010, May. 2010. Available at: http://cibworld.xs4all.nl/dl/ publications/w078_pub361.pdf\#page ${ }^{1 / 446}$

116. Xie H., Shi W., Issa RR. Using RFID and Real-Time Virtual Reality Simulation for Optimization in Steel Construction. Journal of Information Technology. 2011; 16(Feb 2011): 291-308. 